\title{
bog Geeológico
}

Boletín Geológico, 48(2), 107-129, 2021

https://doi.org/10.32685/0120-1425/bol.geol.48.2.2021.584

\section{(c) (i)}

This work is distributed under the

Creative Commons Attribution 4.0 License.

Received: May 25, 2021

Revision received: August 9, 2021

Accepted: September 12, 2021

Published on line: November 5, 2021
Yuruma Formation (Barremian - lower Aptian?) In the Yuruma hill and Punta Espada, Alta Guajira, Uribia, Colombia

\author{
Formación Yuruma (Barremiano - Aptiano inferior?) en el cerro \\ Yuruma y Punta Espada, Alta Guajira, Uribia, Colombia
}

Pedro Patarroyo $^{1}$

1 Departamento de Geociencias, Universidad Nacional de Colombia, Bogotá, Colombia.

Corresponding author: pcpatarroyog@unal.edu.co

\section{A BSTRACT}

The Yuruma Formation in the Yuruma hill area its type locality can be differentiated into two stratigraphic intervals. The lower and upper intervals of the Yuruma Formation can also be subdivided into two segments. The lithological, sedimentological and fossiliferous characteristics support this differentiation, which allows to interpret the accumulation energy influences over the sea floor. The lower interval is characterized by intercalations of very fossiliferous marlstones and biomicrites with benthonic and nektonic fossils from the lower Barremian. The upper interval is represented by marlstones and biomicrites with poor benthonic and nektonic fossils from the upper Barremian and probably from the lower Aptian. In the Punta Espada area, whit scarce lithological controls over the lower and upper parts of the Yuruma Formation, were found biomicrites with benthonic and nektonic fossils of the lower Barremian to the lower part, and to the top were recognized biomicrites that underlie beds with lower Aptian ammonites.

Keywords: Yuruma Formation, lower cretaceous, type locality, La Guajira, Colombia.

\section{RESUMEN}

La sucesión de los depósitos de la Formación Yuruma, con base en la sección del cerro Yuruma, su localidad tipo, se puede diferenciar en dos intervalos estratigráficos, el inferior y el superior, que a su vez pueden subdividirse en dos segmentos cada uno. Las características litológicas, sedimentológicas y fosilíferas sustentan esta diferenciación, permitiendo interpretaciones de la energía de acumulación sobre el fondo del depósito. El intervalo inferior está caracterizado por presentar intercalaciones de lodolitas calcáreas muy fosilíferas y biomicritas con fósiles bentónicos y nectónicos del Barremiano inferior. El intervalo superior se caracteriza por presentar lodolitas calcáreas y biomicritas con poca fauna bentónica y nectónica del Barremiano superior y posiblemente de

Citation: Patarroyo, P. (2021). Yuruma Formation (Barremian - lower Aptian?) In the Yuruma hill and Punta Espada, Alta Guajira, Uribia, Colombia. Boletín Geológico, 48(2), 107-129. https://doi.org/10.32685/0120-1425/bol.geol.48.2.2021.584 
parte del Aptiano inferior. Para el sector de Punta Espada, a partir de reconocimientos puntuales de la parte inferior y superior de la Formación Yuruma, se identificaron respectivamente biomicritas con fósiles bentónicos y nectónicos del Barremiano inferior y biomicritas del techo de la unidad a pocos metros del registro de amonitas del Aptiano inferior.

Palabras clave: Formación Yuruma, Cretáceo inferior, localidad tipo, La Guajira, Colombia.

\section{INTRODUCTION}

Knowledge of the Cretaceous lithostratigraphic units of the Alta Guajira, Colombia (Figure 1) continues to be scarce, and the few publications related to the Cretaceous stratigraphy and paleontology of the La Guajira Peninsula are not very detailed. Renz (1956, 1960), Bürgl (1960) and Rollins (1960, 1965) introduced valuable stratigraphic data but did not illustrate the fossils reported. Zuluaga et al. (2009) synthesized the existing Cretaceous stratigraphy into geological maps. Salazar (2010) investigated the Palanz Formation, which involves continental and transitional deposits. Patarroyo (2020) and Patarroyo and Götz (2020) described the Barremian and Aptian deposits and fossils. Based on ammonites, other mollusks and echinoderms, Renz (1956, 1960), Bürgl (1960), Rollins (1960, 1965), Patarroyo (2020) and Patarroyo and Götz (2020) recognized the existence of calcareous deposits of the Lower Cretaceous in the Alta Guajira.

The sedimentary succession and fossil association of the Yuruma Formation (Alta Guajira) allow a separation in intervals and stratigraphic ranges, which clearly involve the Barremian and probably the lower part of the lower Aptian, providing evidence of the sedimentological and environmental differences related to the contemporary deposits of the Cretaceous basin in central Colombia.
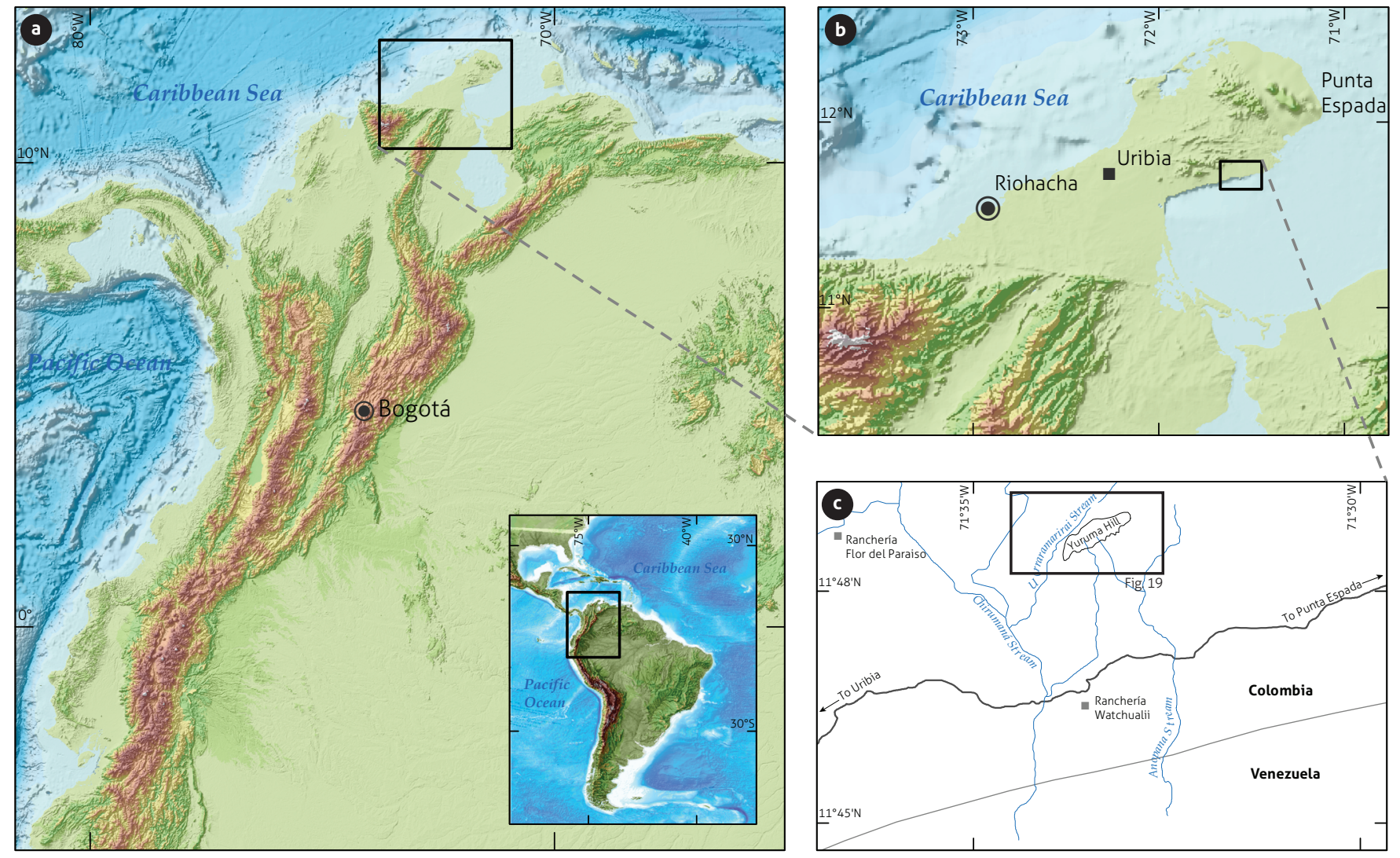

Figure 1. Location of the study area

a) location of La Guajira in northern Colombia; b) department of La Guajira, with the locations of Riohacha, Uribia and Punta Espada; c) Yuruma hill sector, near to ranchería Watchuali (IGAC, Instituto Geográfico Agustín Codazzi), 10Bis-I-A topographic map. 
Thus, the present contribution seeks to provide data on the lithostratigraphy, nomenclature and biostratigraphy of the Yuruma Formation in its type locality, as well as nearby outcrops located to the north in Punta Espada (Uribia, La GuajiraColombia).

\subsection{Location}

Yuruma hill is located at $8.5 \mathrm{~km} \mathrm{~N}$ of ranchería Wuatchuali (in the Wayuunaiki language) or Wuatchuari (Spanish), approximately $90 \mathrm{~km}$ from the urban center of Uribia, in the La Guajira Peninsula (Figure 1) and very close to the border with Venezuela; to the NE of this sector, Punta Espada is located approximately $70 \mathrm{~km}$ away.

\section{METHOD}

The initial input focused on a bibliographic analysis, which allowed the locations of the areas of interest to be recognized, including the Cretaceous sedimentary succession and the Yuruma Formation deposits in the Alta Guajira.

Since mid-2009, based on personal research carried out in the Punta Espada area, the Cretaceous deposits and marine fossils of the Alta Guajira (Patarroyo, 2011, 2020; Patarroyo and Götz, 2013, 2014, 2020) have been recognized from field trips by the Department of Geosciences at the Universidad $\mathrm{Na}$ cional de Colombia in Bogotá. Later, between the end of February and the beginning of March 2018, under the auspices of the Servicio Geológico Colombiano, the Yuruma hill (Figure 2) was surveyed to advance the work related to the book of The Geology of Colombia (Patarroyo, 2020). During this last visit, since the base (northwestern side) until the upper part of the Yuruma hill (side southeast), the sedimentary succession was measured using a Jacob's staff; additionally, rock samples and macrofossils were collected, and the thickness and geometry of the beds were determined following Campbell (1967), moreover comparatively was obtained the color of the rocks with a reference table. To achieve continuous recognition of the succession, bed levels were followed laterally, therefore controls were performed at different sites of the hill, from which four partial columns were obtained.

The rock samples allowed a conventional macroscopic description of the different types of lithologies. The macrofossils were collected directly in the field, prepared or cleaned with conventional techniques using hammers, chisels, needles and pneumatic hammers. These fossils were coated with ammonium chloride, photographed and then digitally processed. The fossil taxonomy is mainly based on Jaworski (1938), Etayo-Serna (1985), Guzmán (1985) and Patarroyo (2020).
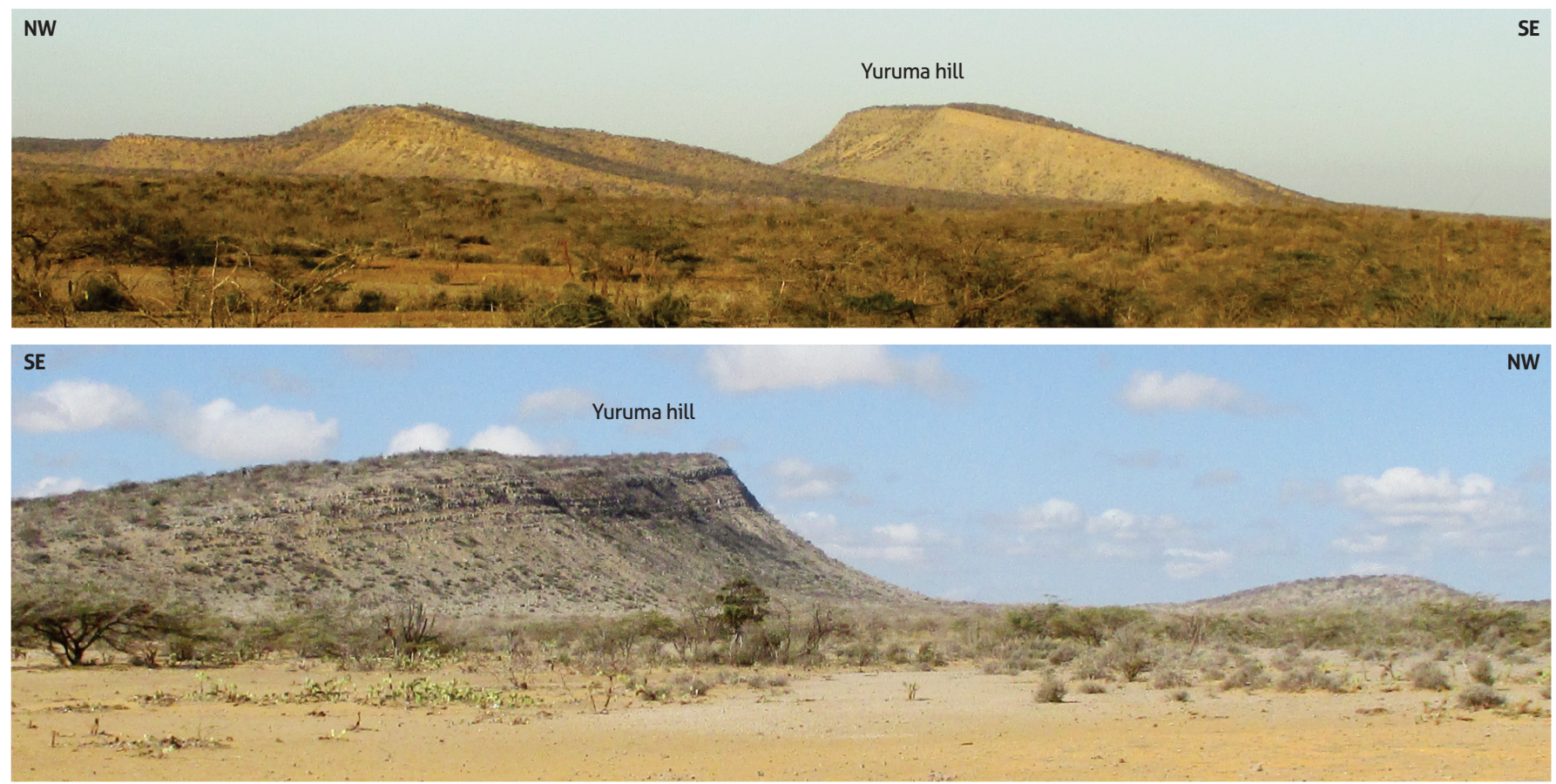

Figure 2. Panoramas of the Yuruma hill north of ranchería Wuatchuali from two locations to the SW and NE 
In Punta Espada area, with the help of the collected fauna, were identified lower Barremian deposits of the Yuruma Formation (Patarroyo, 2011, 2020) and higher stratigraphically probably lowest Aptian deposits of the Yuruma Formation because they underlay beds with lower Aptian ammonites (Patarroyo and Götz, 2020).

\section{Geological framework}

The geology in the continental northern area of Colombia is very particular because the Caribbean plate has exerted a great tectonic influence on the geological blocks in this area, so regionally, the Oca, Cuisa (or Cuiza) and Huimatirra faults are recognized (cf. Álvarez, 1967; Colmenares et al., 2019; Gómez, 2001; Irving, 1971; MacDonald, 1964, 1965; Patarroyo and Götz, 2020; Renz, 1960; Rollins 1960, 1965), which constitute the main lineaments of the allochthon blocks of the Media and Alta Guajira. The Oca and Cuisa faults (Figure 3) are considered dextral strike-slip faults, so they have continuity toward Venezuela. To the south and north of the Cuisa Fault, it is possible to find Cretaceous deposits, whose rock bodies are recog- nized under the same names. The Cretaceous deposits of the Alta Guajira are included in the Palanz, Moina, Yuruma, "Cogollo", "Maraca", "La Luna", Guaralamai and Parauinkrein (Parabanclen) formations, following Renz (1960), Bürgl (1960), Rollins (1960, 1965), Zuluaga et al. (2008 a and b, 2009), Salazar (2010), Patarroyo $(2011,2020)$ and Patarroyo and Götz $(2013,2014,2020)$.

\subsection{Nomenclature of the Yuruma Formation}

The Yuruma Formation is one of the lithostratigraphic units that includes marine deposits of the Lower Cretaceous of the Alta Guajira. Rollins $(1960,1965)$ and Julivert et al. (1968) indicate that the denomination Yuruma was first used by geologists at the Richmond Exploration Company in approximately 1947.

Related with Yuluma (in the Wayuunaiki language) or Yuruma (Spanish) hill, the lithostratigraphic denomination arises under the term Yuruma Formation, formalized by Renz (1956) to refer to a Hauterivian - Barremian succession, which differentiated into "lower Yuruma" and "upper Yuruma". Later, Renz (1960) restricted the term Yuruma Formation to the

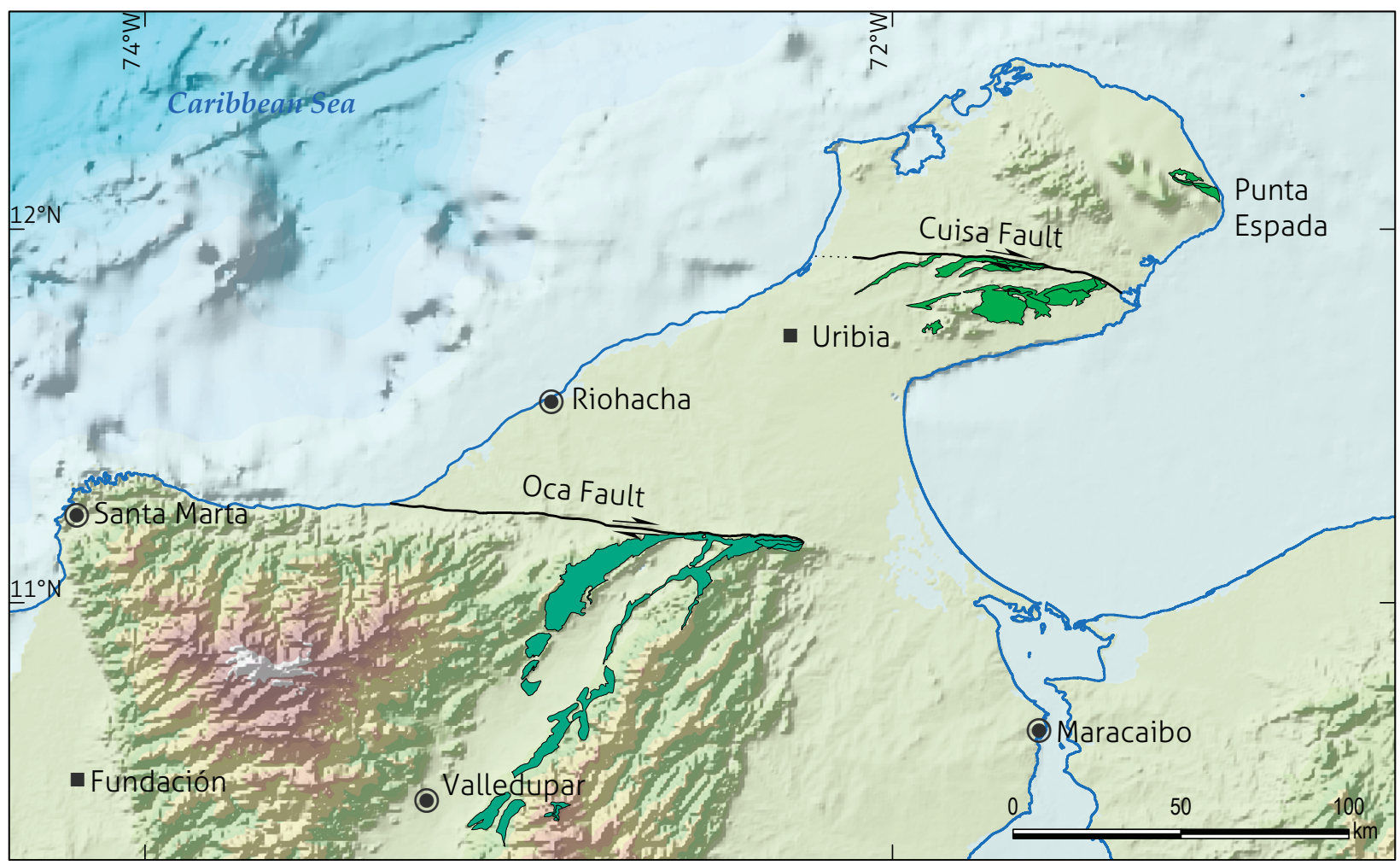

Figure 3. Location of the La Guajira province, showing the outcrop distribution of the Cretaceous deposits to the south and north of the Oca and Cuisa faults General location in Figure $1 \mathrm{~b}$. 
Table 1. Comparative diagram of the lithostratigraphic units of the Lower Cretaceous and their stratigraphic range and limits

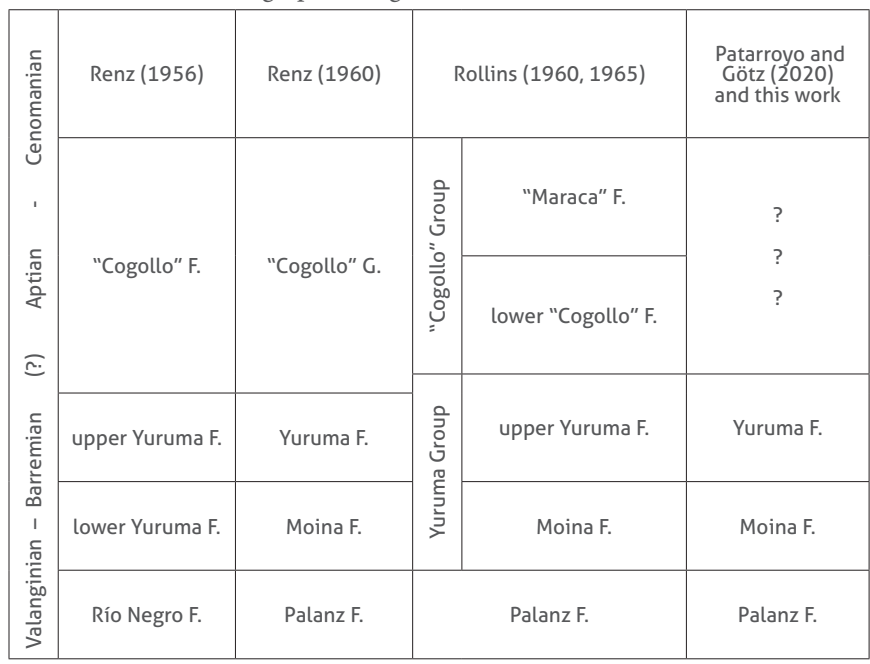

Source: Based on Renz $(1956,1960)$, Rollins $(1960,1965)$, and Patarroyo and Götz (2020).

"upper Yuruma" succession with Barremian fossils, so he designated the "lower Yuruma" as the Moina Formation.

According to the proposal of Renz (1960), the Yuruma Formation underlies the Moina Formation of the Valanginian - Hauterivian (in the sense of Rollins, 1960, 1965) or the "lower Yuruma" of Renz (1956), which underlies the "Cogollo" Formation. Notably, Rollins $(1960,1965)$ modified the top boudary of the Yuruma Formation, placing it higher stratigraphically (Table 1), therefore the succession becomes thicker than that considered by Renz (1960). It means that according to Renz $(1956,1960)$, part of the lower interval of the Cogollo
Formation became the highest segment of the Yuruma Formation (Rollins 1960, section BB' and plate 4 of the geological map of the La Guajira Peninsula; 1965) proposal followed in this study.

Related with the type locality, Rollins $(1960,1965)$ indicated a thickness of $269 \mathrm{~m}$ for the upper Yuruma, which should be understood as the succession of the Yuruma Formation. Although there are other known outcrops of the Yuruma Formation in the Alta Guajira, which, according to the literature, show some thickness and lithological variations, in the Yuruma hill (Figure 2), there is a very good exposure. Some outcrops near Punta Espada, NE of the type locality, are recognized by Barremian fossil fauna; thus, they are associated with this lithostratigraphic unit, as also was recognized by Renz (1960), Bürgl (1960), Rollins $(1960,1965)$, Patarroyo $(2011,2020)$ and Patarroyo and Götz $(2013,2014,2020)$.

\section{Results}

The literature analysis, moreover the fieldwork in the Yuruma hill and in the Punta Espada area, were the fundamental inputs to obtaining the results of this contribution.

\subsection{Lithostratigraphy}

At the base of the Yuruma hill, along the Uarraramarirai or Uarramaralijai Stream (Figures 1c and 4), the sharp contact between the bioclastic levels with ostreids to the top of the Moina Formation and the marlstones at the base of the Yuruma Formation is observed. There structural orientation of the beds toward the lithostratigraphic boundary is $\mathrm{N} 70^{\circ} \mathrm{E} / 11^{\circ} \mathrm{SE}$.
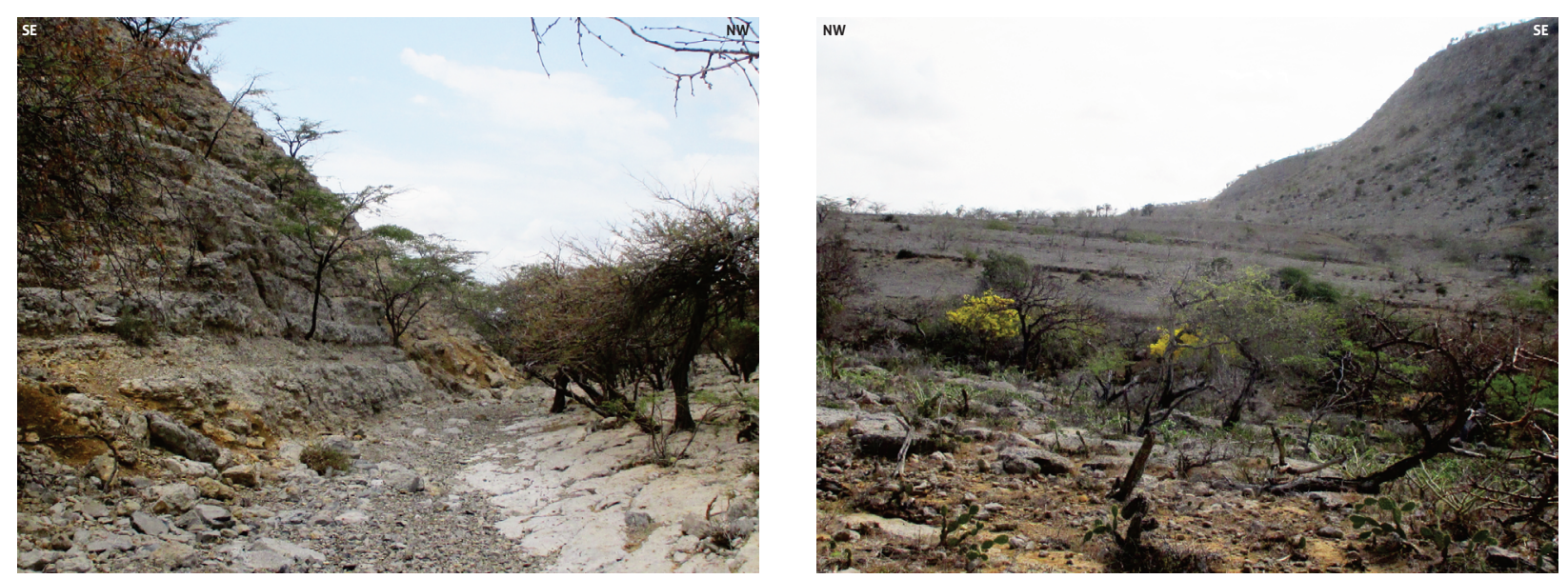

Figure 4. Surface of the sharp contact between the top bed of the Moina Formation and the base of the Yuruma Formation, Uarraramarirai Stream Lower Yuruma hill section 
A large part of the succession described here, since the base (Uarraramarirai or Uarramaralijai stream) until the upper part of Yuruma hill, has a thickness of approximately $190 \mathrm{~m}$ (Figures 2 and 5), measured directly with a Jacobs staff and with glo- bal positioning system (GPS) control. Based on fieldwork and lithological characteristics, the succession can be divided into two stratigraphic intervals (Figure 5), coinciding with observations proposed by Rollins $(1960,1965)$. The lower interval,

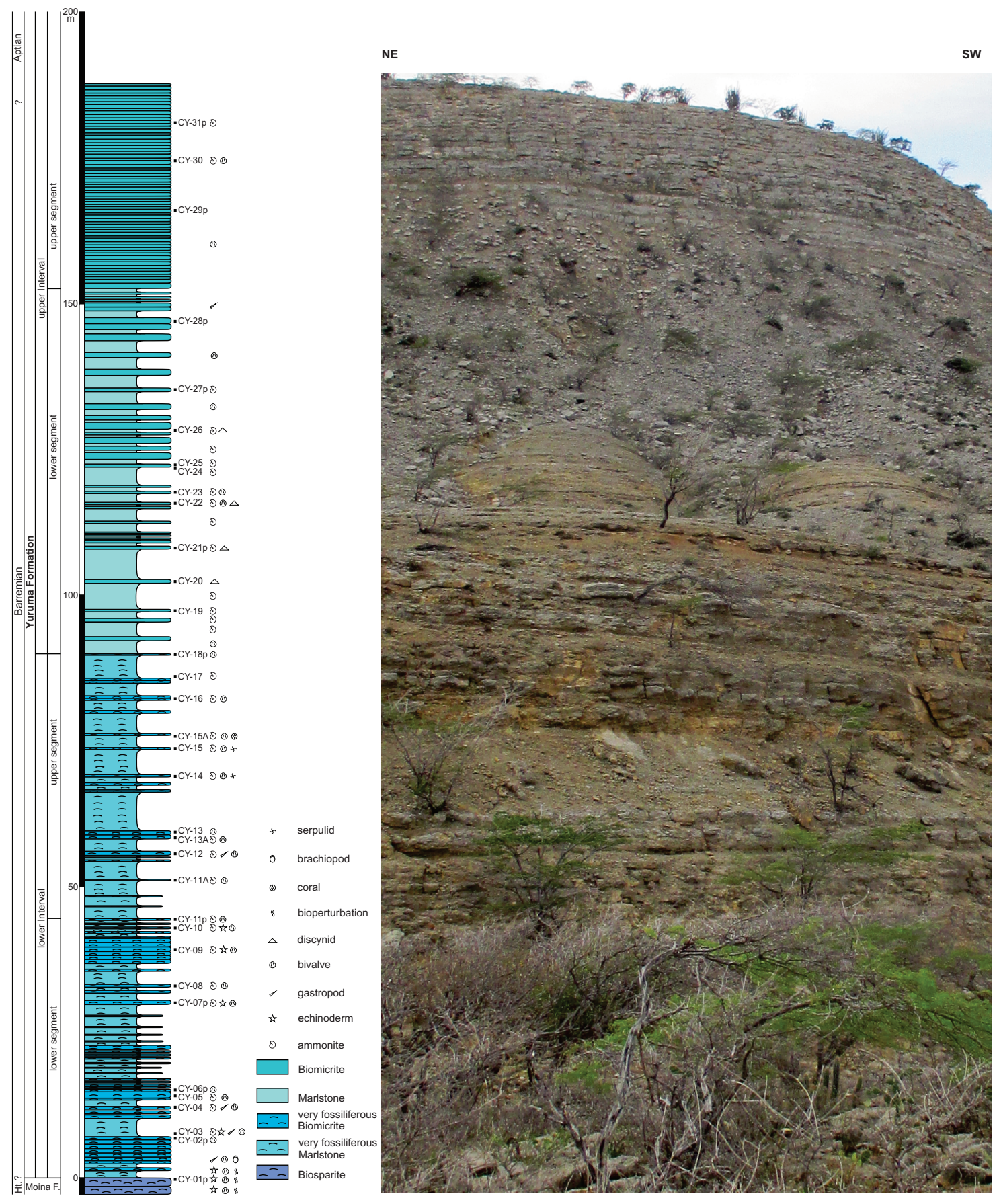

Figure 5. Stratigraphic section of the sedimentary succession of the Yuruma Formation in the Yuruma hill area and panoramic view of the succession since the Uarraramarirai Stream until the upper part of the hill (Uribia, La Guajira)

Includes the top of the Moina Formation and a large part of the Yuruma Formation. 
$90 \mathrm{~m}$, shows intercalations of very fossiliferous to fossiliferous biomicrites and very fossiliferous marlstones with mollusks, echinoids, articulated brachiopods, serpulids and colonial corals, with thin to very thick beds and irregular to regular geometries. To the upper interval was possible to described only $100 \mathrm{~m}$ (Figure 5), without reaching the top of the unit, represented by intercalations of poor fossiliferous biomicrites and marlstones. The fossil content of this interval varies markedly compared with its underlying beds because the fossil amount decreases. In addition, benthic organisms are scarce and the few that exist have thin shells (bivalves and disarticulated brachiopods). Likewise, the change in the sedimentological characteristics is perceived; there is a tabular geometry in the beds with flat to parallel wavy lamination, scarce macrofauna (microfauna is predominant) and without fragmentation of the fossils.

The upper boundary with the "Cogollo" Formation was not recognized in the Yuruma hill area in this study. Based on Rollins (1960, Figure 6, BB' section and plate 4 of the geological map of the La Guajira Peninsula; 1965, Figure 6), for this sector, the boundary of the Yuruma Formation is found at the limestones with ostreids in the SE margin of the Yuruma hill. In the sector of the Punta Espada, following Patarroyo and Götz (2020), the upper boundary of the Yuruma Formation is located in the highest structural plane of biomicrites of the upper interval, coinciding with a very prominent morphological change (Figure 6).

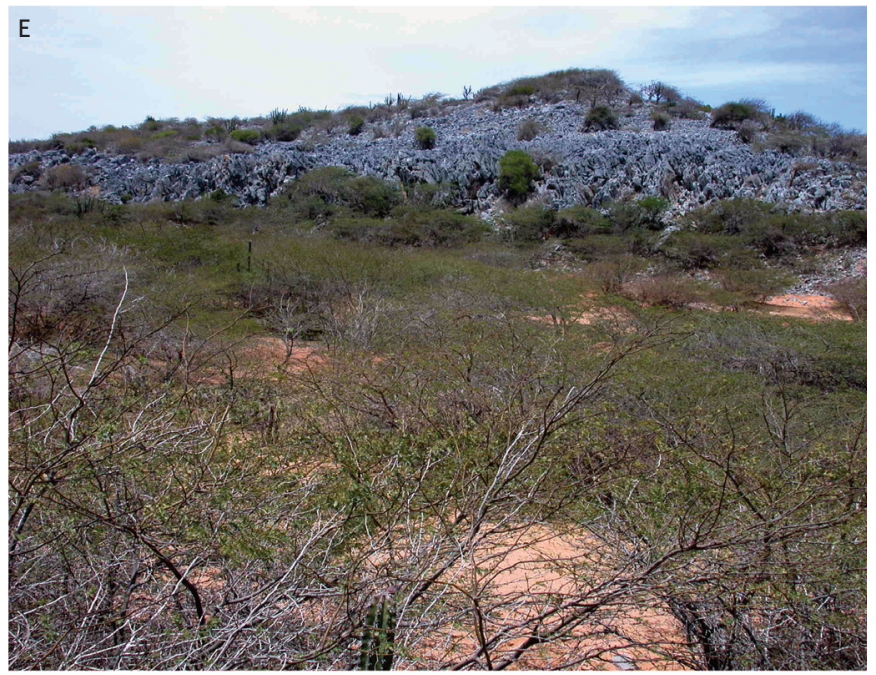

Similarly, each of the aforementioned intervals can be subdivided into two segments. For the lower interval, the lower segment (Figures 5, 7 and 8) has $44.5 \mathrm{~m}$ of intercalations, in which there is a greater predominance of biomicrites (N1-N5) with irregular geometries of thin, medium and thick beds on very fossiliferous marlstones (N1) (Figure 8).

Whole fossils are in the marlstones, while in the biomicrites, thick-shelled benthic fossils are more frequent, which present principally aleatory distributions and, in many cases, fragmentation. There may also be bioperturbations in some of the strata.

The upper segment of the lower interval (Figures 5 and 7), with thickness of $45.5 \mathrm{~m}$, has a higher proportion of marlstones (N1) than biomicrites (N1-N5). The marlstone beds are very thick, and the biomicrite layers are medium to thin. The fossils in the marlstones show parallel orientations according to the stratification plane, while in the biomicrites, the thick shell benthic fossils mainly present aleatory distributions and, in some cases, fragmentation. Bioperturbation may occur in some strata. In the succession of the lower interval, trigonids (Pterotrigonia sp.), ostreids (Ceratostreon sp.), gastropods of variable sizes (Nododelphinula sp.), ammonoids, irregular echinoderms, serpulids, articulated brachiopods, and others are either fragmented or complete (whole).

For the upper interval, the lower segment (Figures 5 and 9) is $65 \mathrm{~m}$ thick with intercalations between weathered marlstones (N1, 5YR 4/1) and biomicrites (N1, N2, N3, N4, 5YR 2/1, 5YR

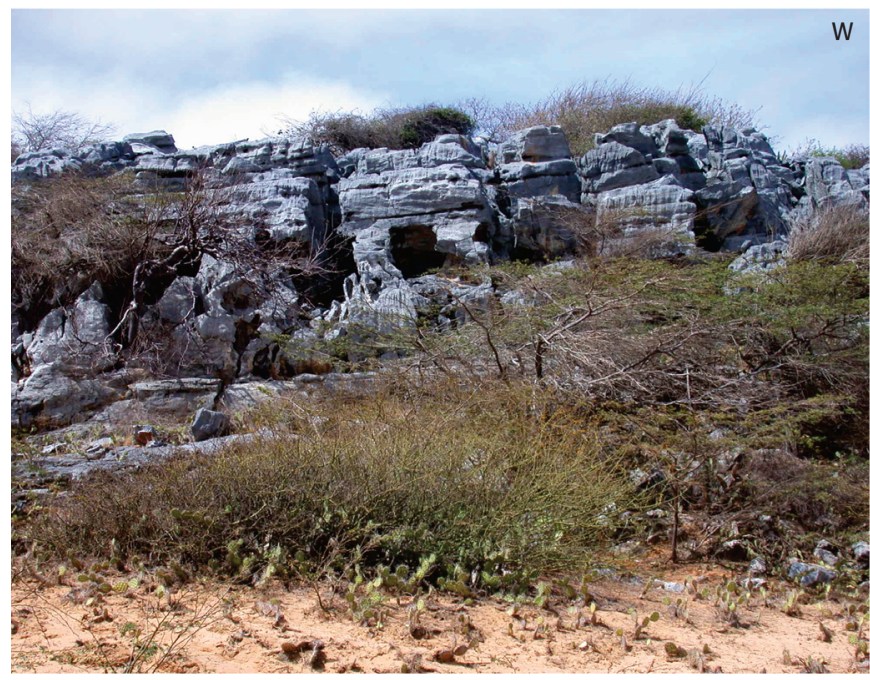

Figure 6. Biomicrite strata at the top of the Yuruma Formation in the Punta Espada area

The morphological change in the structural plane with strong tectonic and karstic effects dips to the N, coinciding with the lithostratigraphic boundary (photographic capture from the N, Piedra del Destino valley, cf. Patarroyo and Götz, 2020, Figure 2). 
4/1, 5YR 6/1). The tabular beds of marlstones are very thick, and the biomicrites are medium thick (Figure 10), mainly with flat parallel lamination. In both the marlstones and biomicrites, the fossils have the same orientations as the bedding plane, and the few benthic fossils (bivalves and discynid brachiopods) have thin shells (Figure 10). In the upper segment of the upper interval (Figures 5, 9 and 10), only $35 \mathrm{~m}$ of strata are described, represented by tabular, medium to thick beds, mainly containing biomicrites with dominantly parallel flat lamination; the benthic and nektonic fauna are scarce, while the microfossils (foraminifera?) are more abundant.

In other controls of the Punta Espada area, thin beds of biomicrite (Figure 11) were recognized, in which abundant benthic fossils with thick shells appear, mainly disjointed and fragmented, and nektonic fossils are less frequent. These lithostratigraphic characteristics are similar to those observed in the lower segment of the lower interval of the Yuruma hill sector.
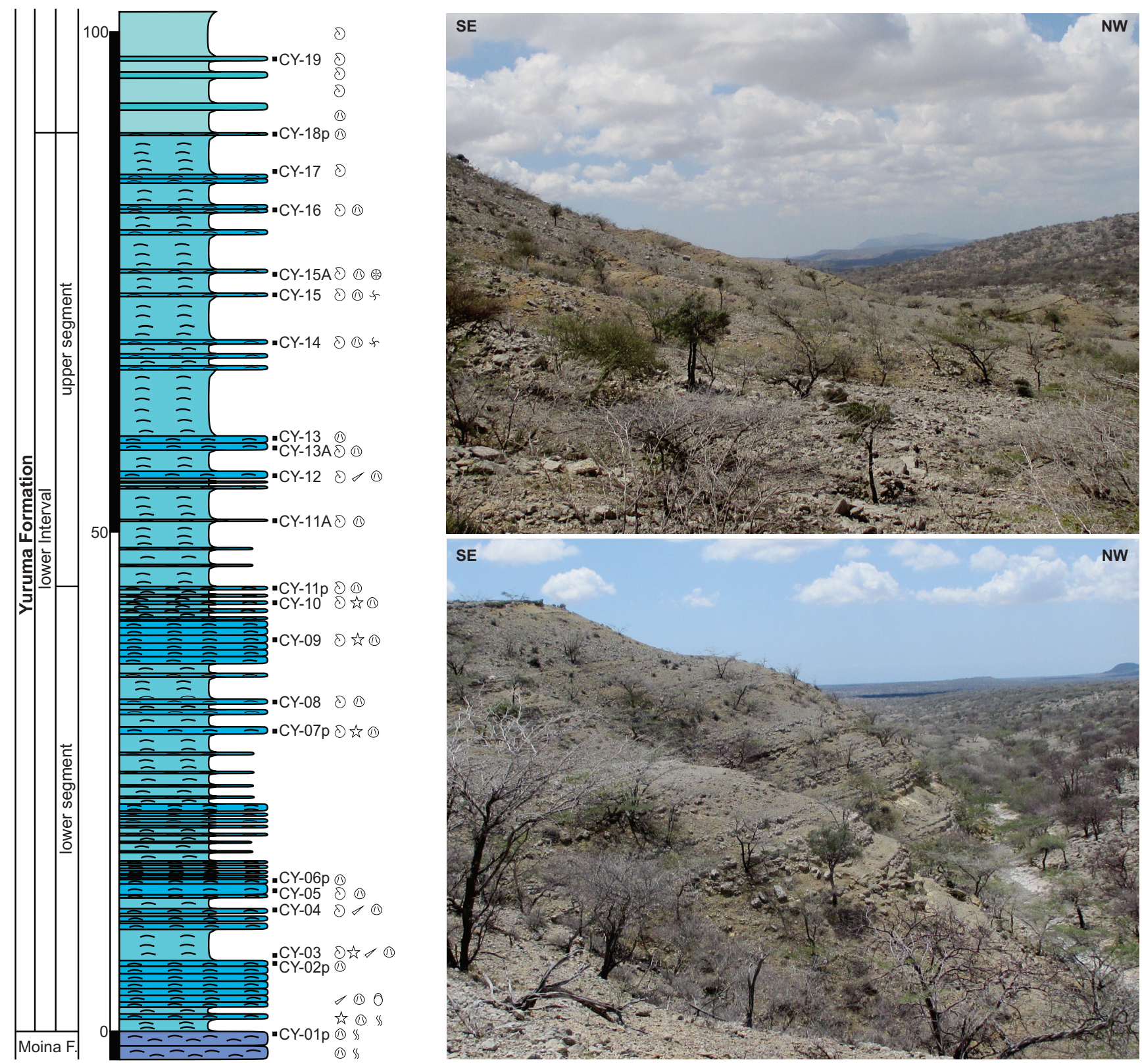

Figure 7. Stratigraphic succession and outcrops of the lower interval of the Yuruma Formation, Yuruma hill section 

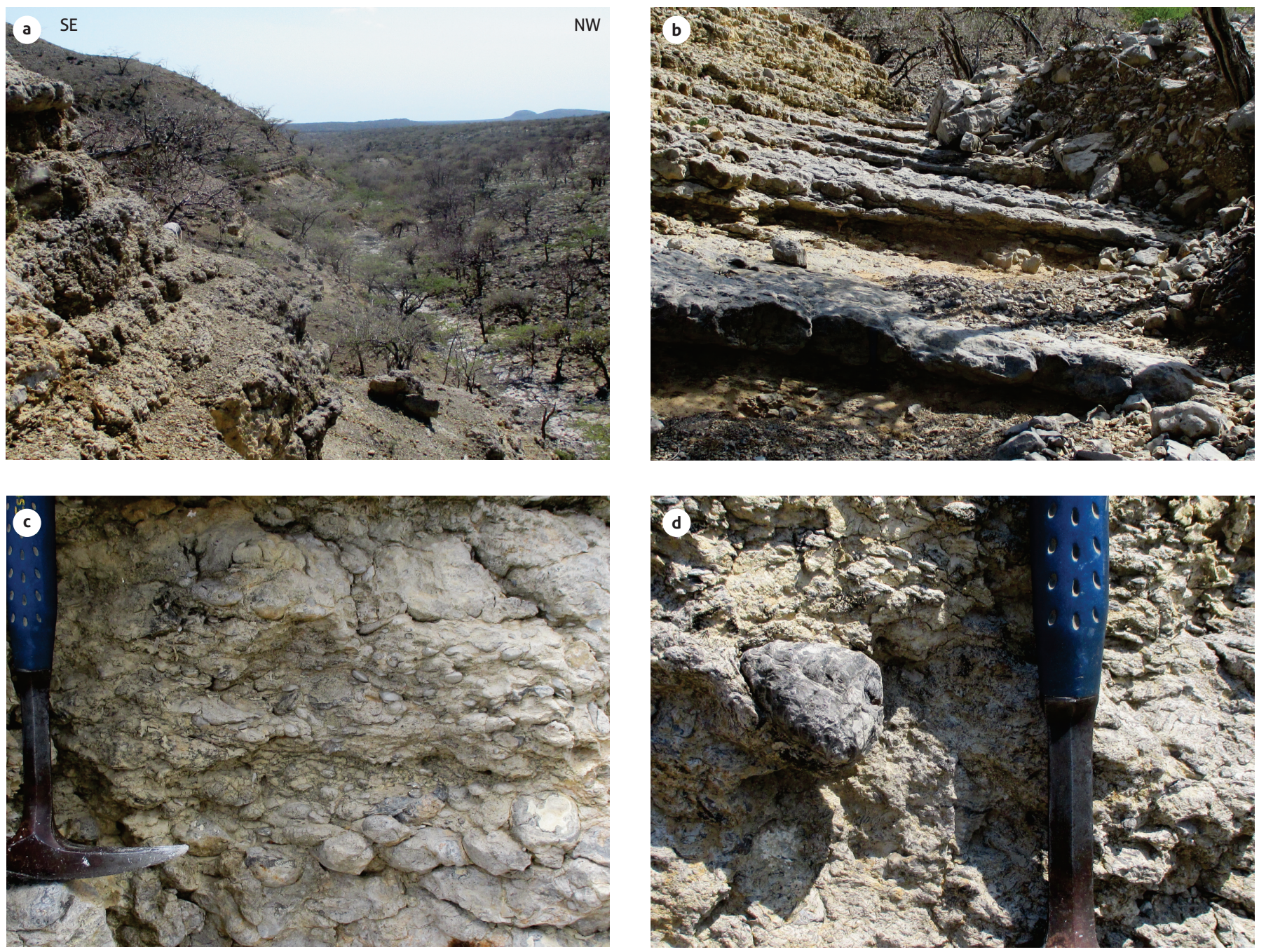

Figure 8. a) Sedimentary outcrops of the entire lower segment of the lower interval of the Yuruma Formation; b) close up picture, where the irregular geometries of the thin beds are notorious (meters 37 to 39); $\mathrm{c}$ and d) fossils and their bed distribution; and d) Pterotrigonia sp. 

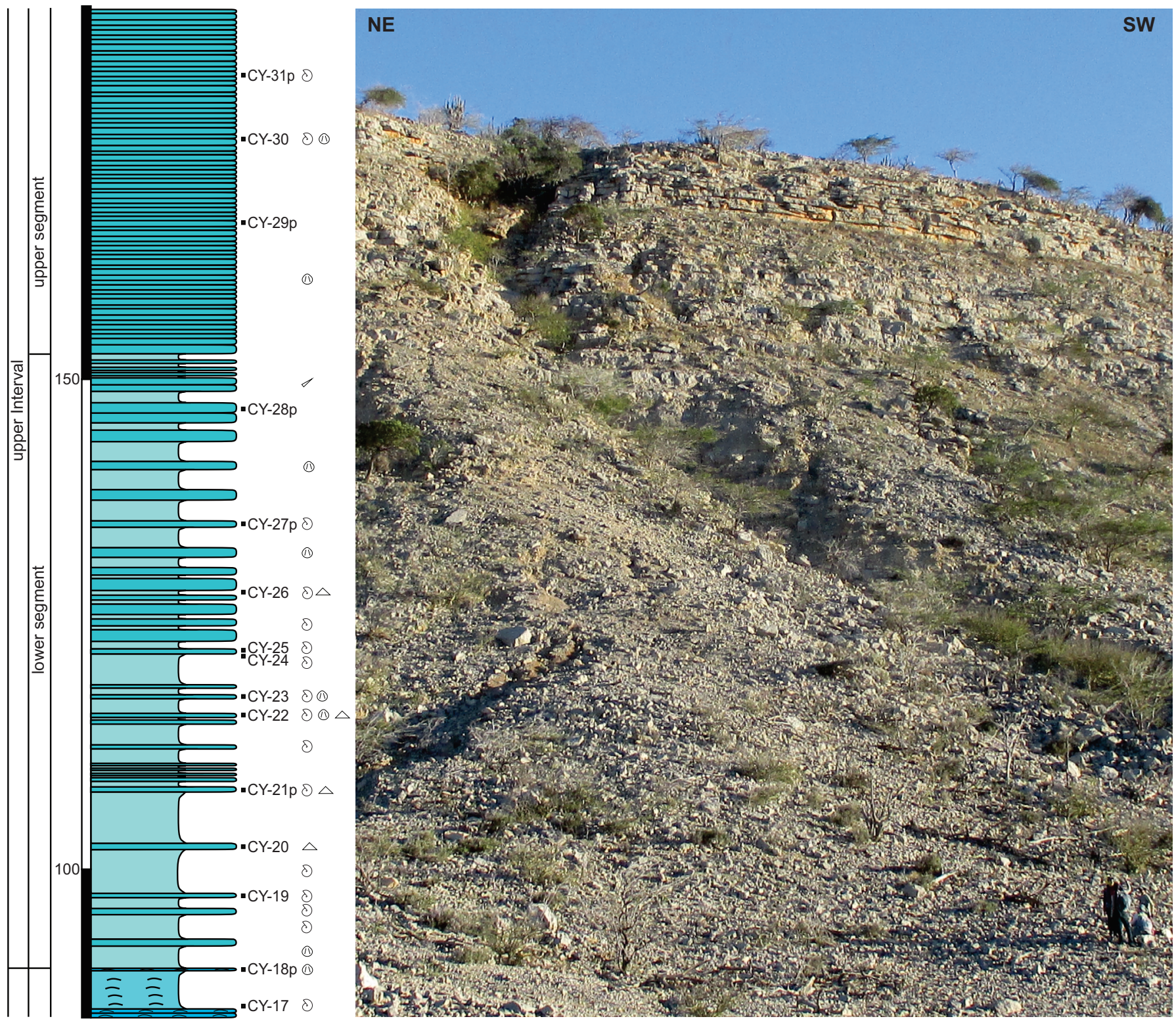

Figure 9. Stratigraphic succession and outcrops of the upper interval of the Yuruma Formation Medium to upper Yuruma hill section. 


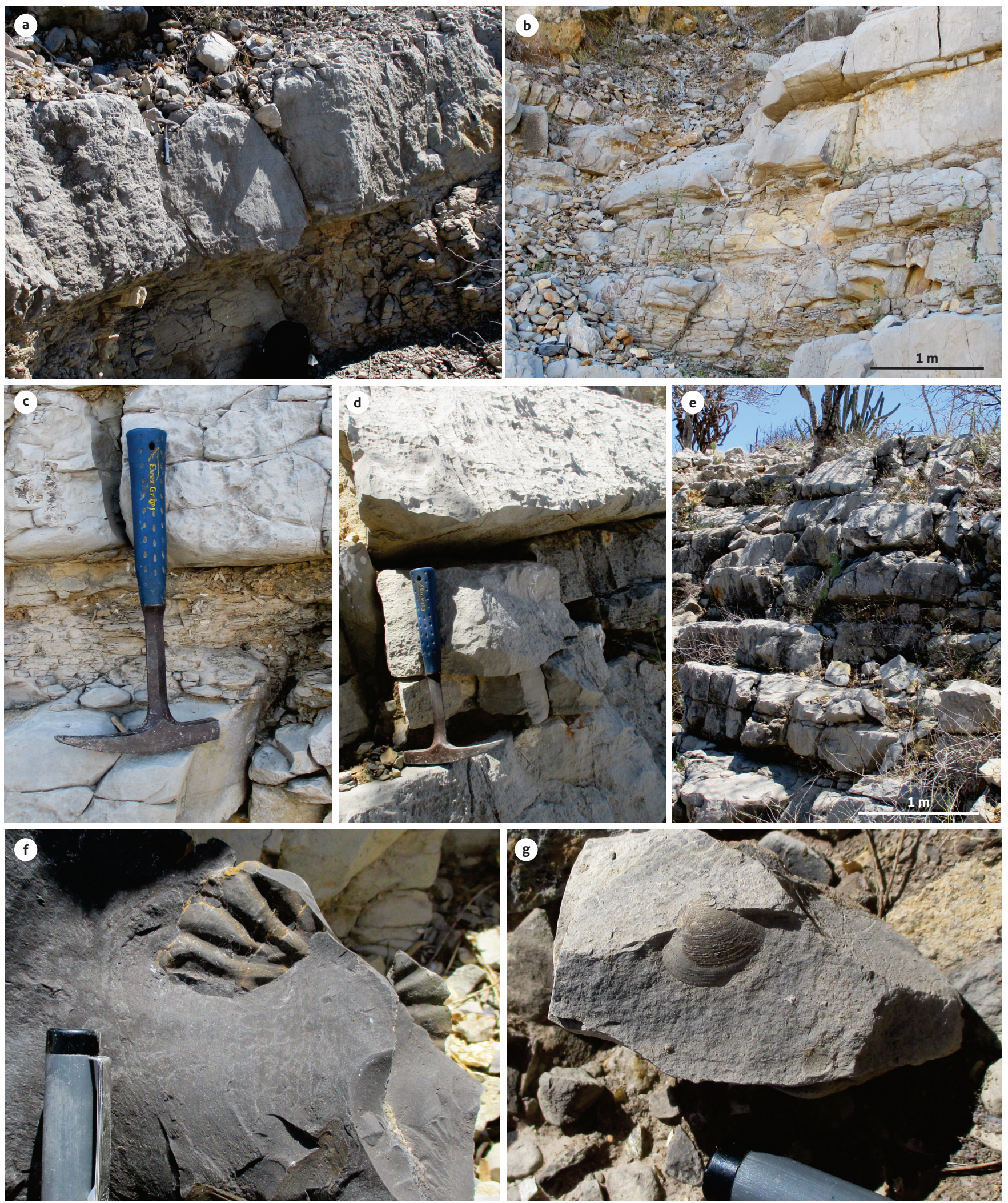

Figure 10. Details of the outcrops of the tabular beds of marlstones and biomicrites of the upper interval and some of their macrofossils

$\mathrm{a}$ and c) biomicrites and weathered marlstones of the lower segment; $b, \mathrm{~d}$ and e) biomicrites of the upper segment; f) biomicrite with an ammonoid fragment; and g) biomicrite with a bivalve, in which soft thickening of the growth lines is observed. Fossils remain in the field. 


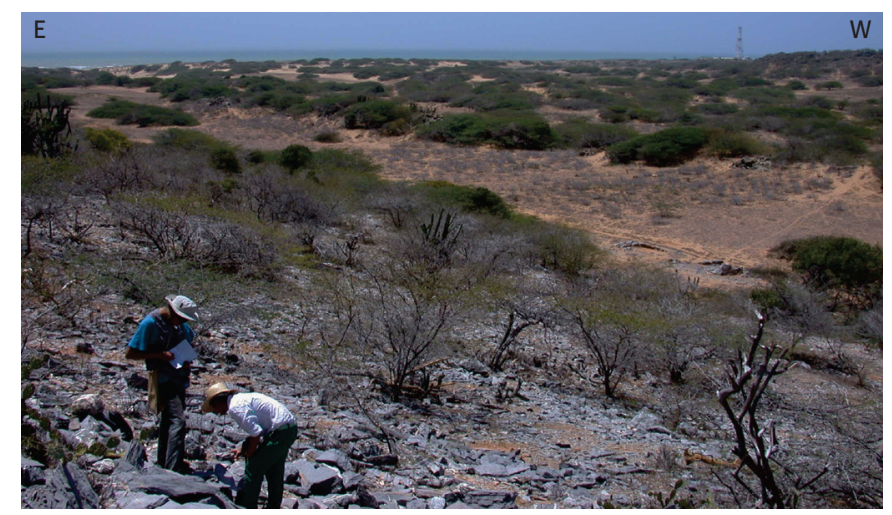

Figure 11. Succession of the lower part of the Yuruma Formation at Punta Espada

In the background, the coastline and the Punta Espada lighthouse can be seen.

\subsection{Biostratigraphy and stratigraphic range}

Based on the fossil vertical distribution, especially the ammonoids, it is possible to identify the stratigraphic range of the Yuruma hill succession following postulates for the equivalent Cretaceous successions of central Colombia.

In the upper section of the Moina Formation (Figure 12), the predominance of the ostreid Ceratostreon sp. may be present in both the Hauterivian and Barremian deposits, a case that is similar to what occurs in the stratigraphic section at the top of the Rosablanca Formation in the middle of Magdalena Valley.

Within the lower segment of the lower interval of the Yuruma Formation (Figure 12), the following fossils are recognized: sample CY-03, Nicklesia pulchella (d’Orbigny, 1840) (Figure 13a), Nicklesia karsteni (Uhlig, 1882) (Figure 13b), Karsteniceras beyrichi (Karsten, 1858) (Figure 13c), Karsteniceras cf. beyrichi (Figure $13 \mathrm{~d}$ and e), and Neithea sp. (Figure 13f); sample CY-04, Karsteniceras cf. beyrichi (Figure 13g, e, i), Karsteniceras sp. (Figure $13 \mathrm{~h}$ ), and Nododelphinula sp. (Figure 13j) in the sense of Jaworski (1938, pl. 23, 5); sample CY-05, Nicklesia cf. karsteni (Figure 13k, 1); samples CY-07 and CY08, Pulchellia galeata (von Buch, 1838) (Figure $13 \mathrm{~m}$ and $\mathrm{n}$ ); sample CY-08, Pulchellia sp. (Figure 13o); sample CY-09, Karsteniceras sp. (Figure 14a); sample CY-10, Pulchellia sp. (Figure 14b), Moutoniceras? sp. (Figure 14c), and Pulchellia cf. galeata (Figure $14 \mathrm{~d}$ and e); and sample CY-11A; Nicklesia pulchella (Figure 14f).

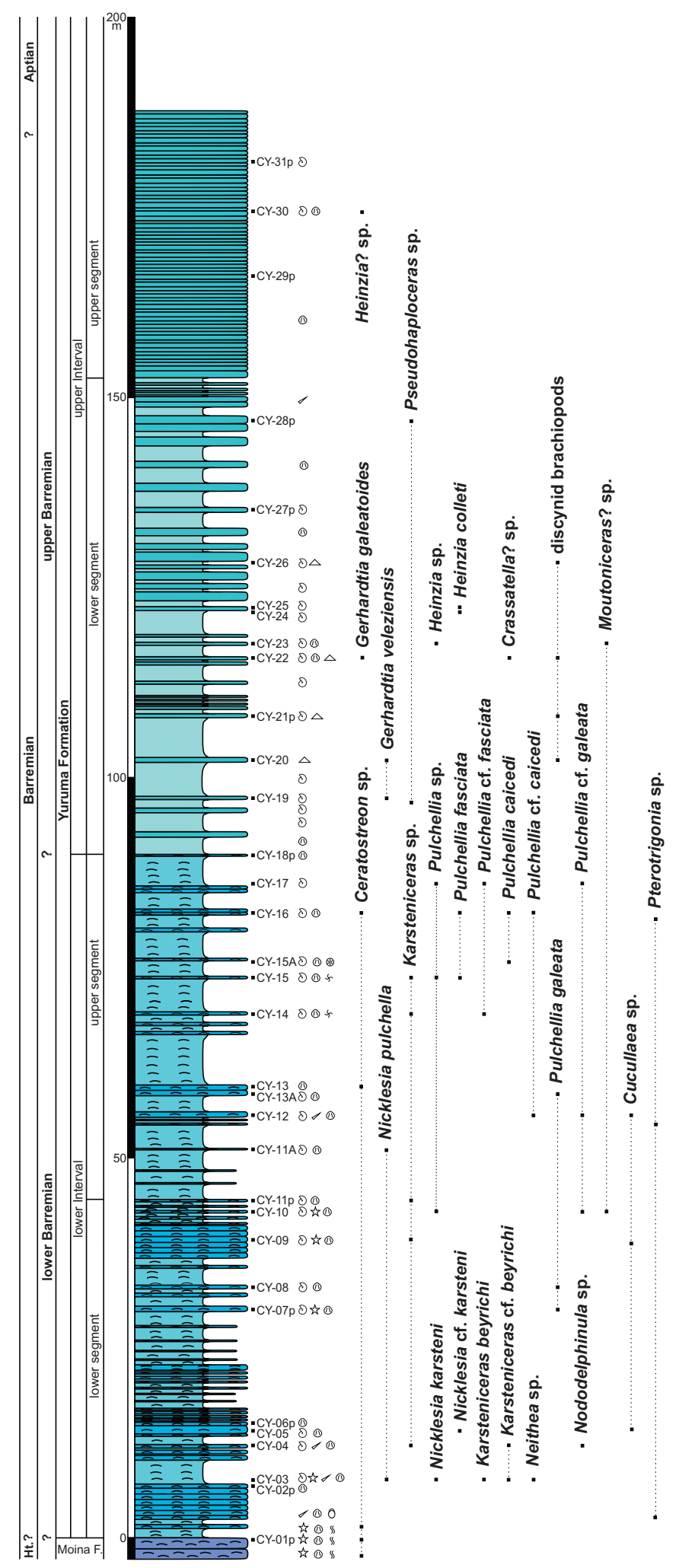

Figure 12. Sedimentary succession of the Yuruma hill section with the vertical fossil distribution 

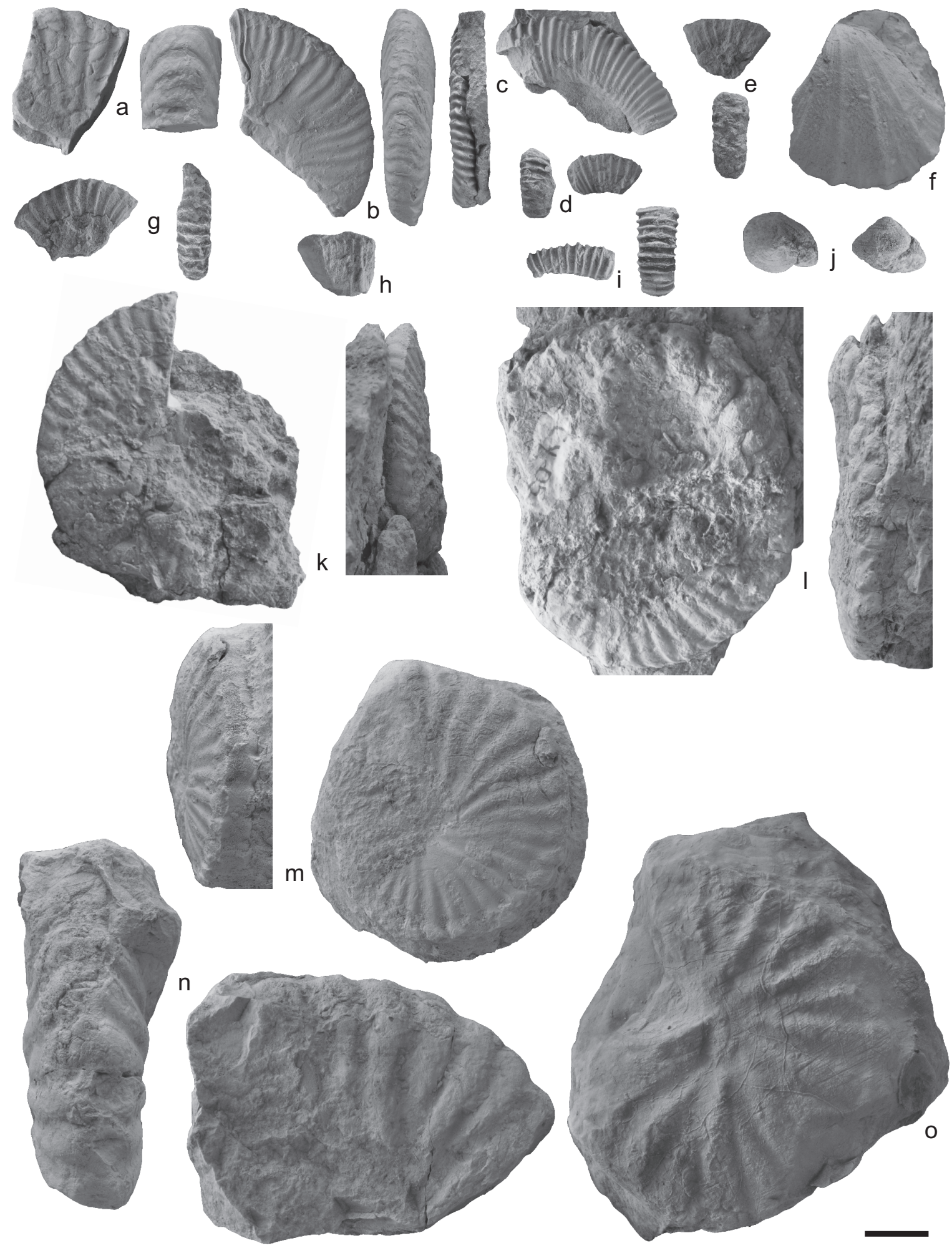

Figure 13. a) Nicklesia pulchella (CY-03); b) Nicklesia karsteni (CY-03); c) Karsteniceras beyrichi (CY-03); d and e) Karsteniceras cf. beyrichi (CY-03); f) Neithea sp. (CY-03); g, e, i) Karsteniceras cf. beyrichi (CY-04); h) Karsteniceras sp. (CY-04); j) Nododelphinula sp. (CY-04); k, 1) Nicklesia cf. karsteni (CY-05); m, n) Pulchellia galeata (CY-07 and CY-08); and o) Pulchellia sp. (CY-08) [Graphic scale: $10 \mathrm{~mm}$ ] 


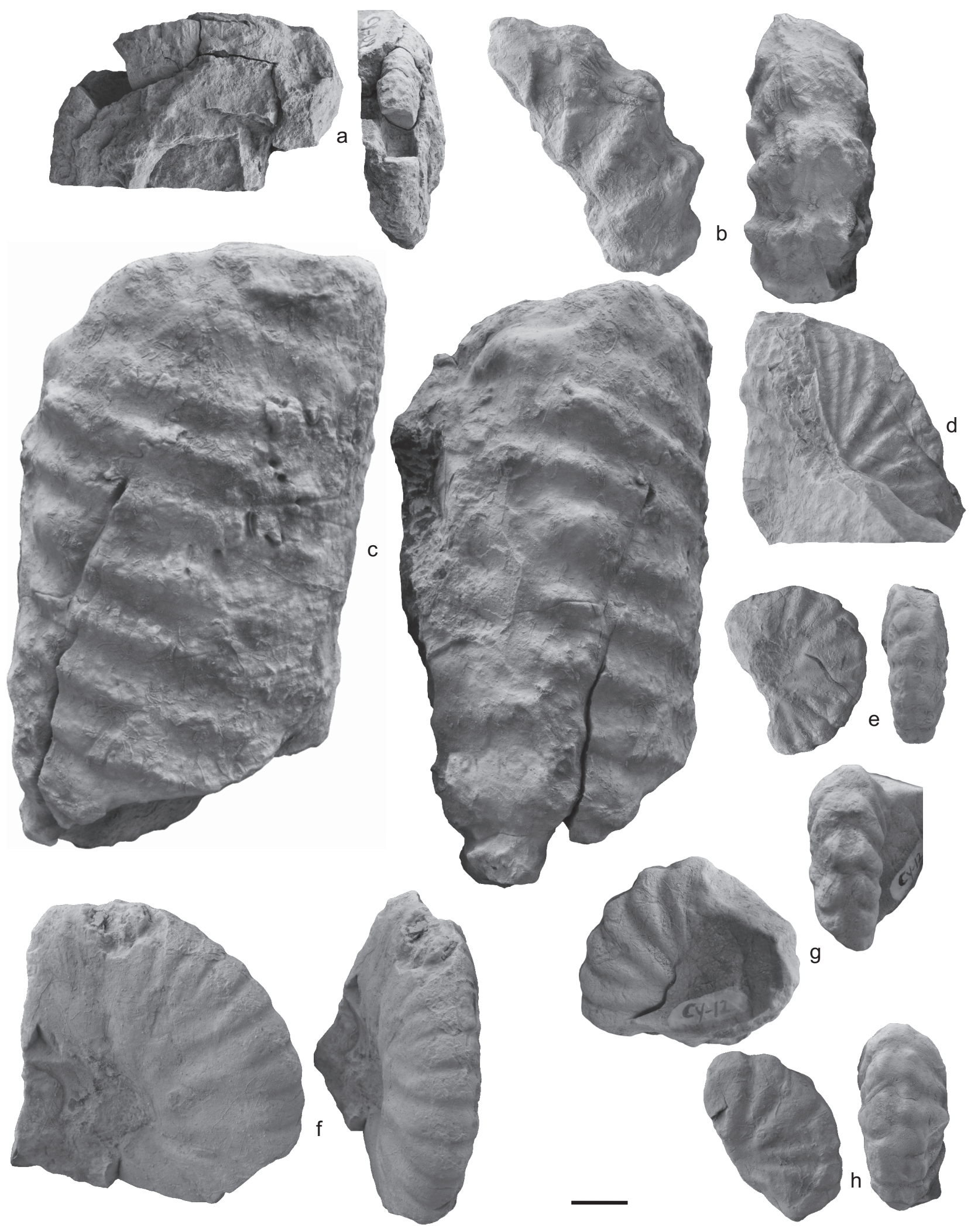

Figure 14. a) Karsteniceras sp. (CY-09); b) Pulchellia sp. (CY-10); c) Moutoniceras? sp. (CY-10); d and e) Pulchellia cf. galeata (CY-10); f) Nicklesia pulchella (CY11A); g) Pulchellia cf. galeata (CY-12); and h) Pulchellia cf. caicedi (CY-12) [Graphic scale: $10 \mathrm{~mm}$ ] 

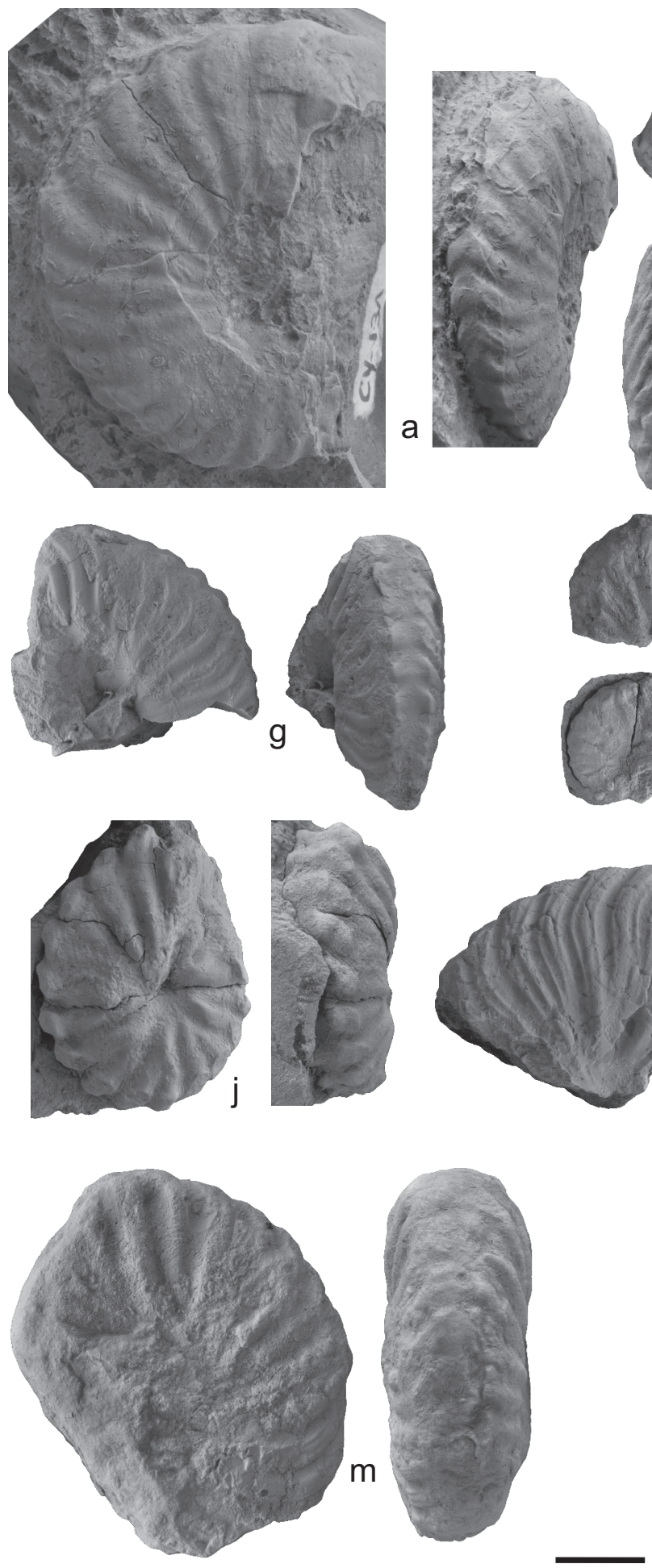
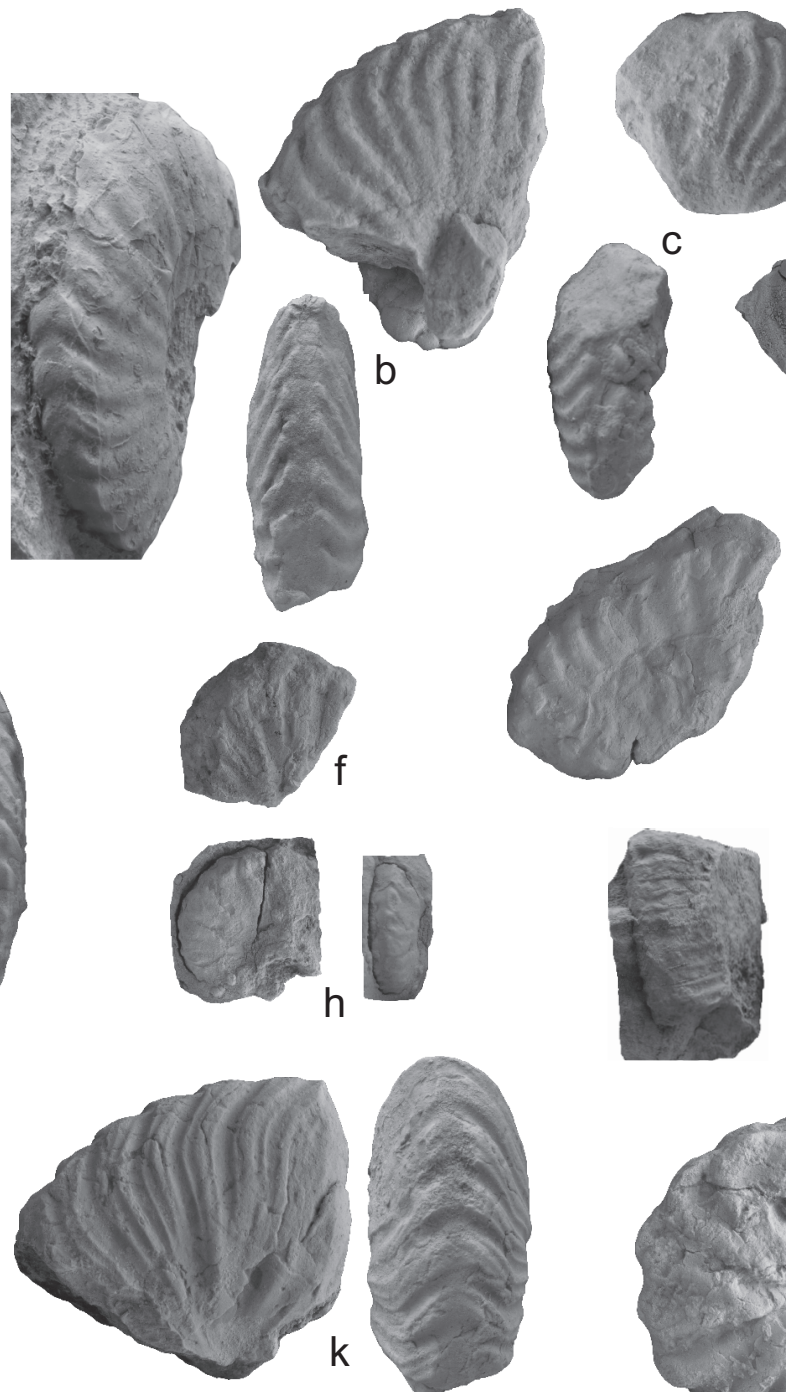

e
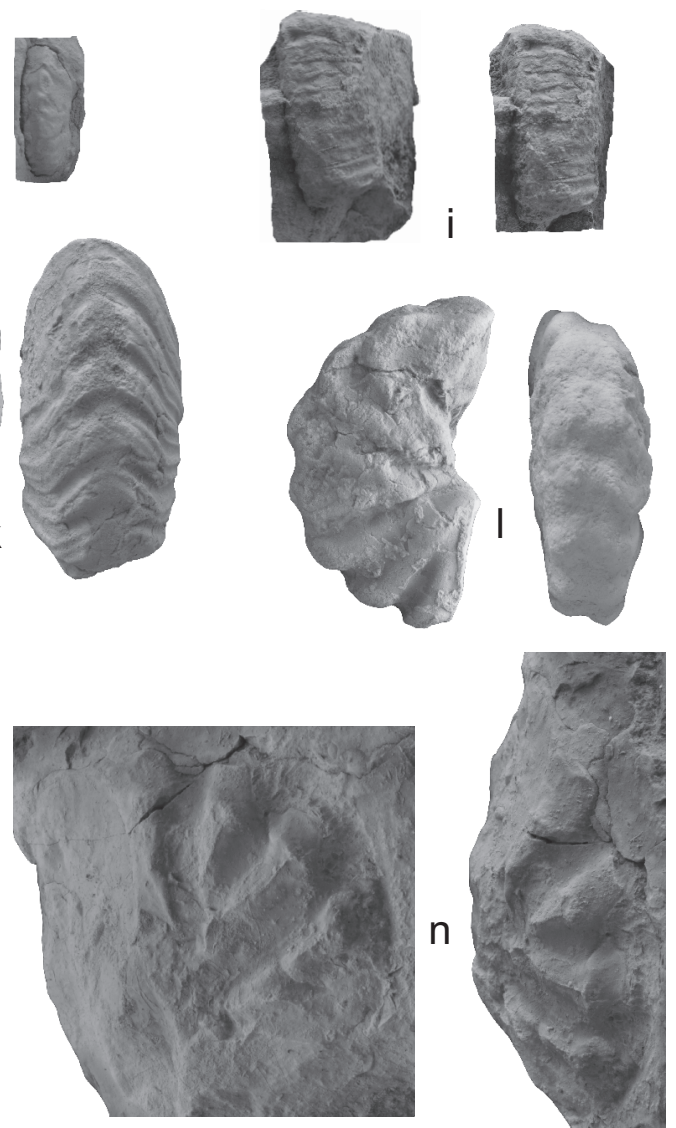

Figure 15. a) Pulchellia galeata (CY-13A); b, c, d, e and f) Pulchellia cf. fasciata (CY-14); g) Pulchellia fasciata (CY-15); h) Pulchellia sp. (CY-15); i) Karsteniceras sp. (CY-15); j) Pulchellia caicedi (CY-15A); k) Pulchellia fasciata (CY-16); 1) Pulchellia cf. caicedi (CY-16); m) Pulchellia cf. galeata (CY-16); and n) Pulchellia caicedi (CY-16) [Graphic scale: $10 \mathrm{~mm}$ ] 
For the upper segment of the lower interval, the following fossils are recognized: sample CY-12, Pulchellia cf. galeata (Figure 14g) and Pulchellia cf. caicedi (Karsten, 1858) (Figure 14h); sample CY-13A, Pulchellia galeata (Figure 15a); sample CY-14, Pulchellia cf. fasciata (Gerhardt, 1897) (Figures 15 b, c, d, e and f); sample CY-15, Pulchellia fasciata (Figure $15 \mathrm{~g}$ ), Pulchellia sp. (Figure $15 \mathrm{~h}$ ) and Karsteniceras sp. (Figure 15i); sample CY-15A, Pulchellia caicedi (Figure 15j); sample CY16, Pulchellia fasciata (Figure 15k); sample CY-16, Pulchellia cf. caicedi (Figure 15l), Pulchellia cf. galeata (Figure 15m) and Pulchellia caicedi (Figure 15n); and sample CY-17, Pulchellia cf. fasciata (Figure 16a), Pulchellia sp. (Figure 16b) and Pulchellia cf. galeata (Figure 16c). In addition, Pterotrigonia sp. (Figure 8d), Ceratostreon sp., Pholadomya sp., Pinna sp., gastropods of small size (Nododelphinula sp.) large (internal molds with low spire), irregular echinoderms (cf. Figure 18), and articulated brachiopods and colonial corals are found.

Thus, based on the ammonoids finding in the lower interval, this stratigraphic section involves deposits of the Lower Barremian taking into account the index species of the unnamed interval biozones of Nicklesia pulchella and Pulchellia galeata (cf. Patarroyo, 1999, 2000 a and b, 2004, 2020).

To the other hand, within the succession of the Lower Barremian of the Yuruma Formation (Figure 12), a stratigraphic level is recognized, in which individuals of Nicklesia and Pulchellia coincide, similar to that is found in the center of Colombia (Patarroyo, 1999, 2000 a and b, 2004, 2020). Given this finding and its constancy through Colombia, from the biostratigraphic point of view, it would be more appropriate to propose a concurrent range subzone for this interval than a new biozone for the lower Barremian. Thus, the subzone in which Nicklesia and Pulchellia coexist is restricted to the lower part of the interval biozone (based on lowest occurrences) of Pulchellia galeata (Patarroyo, 1999, 2000 a and b, 2004, 2020).

In the lower segment of the upper interval, the following fossils are present in the samples: CY-19 and CY-20, Gerhardtia veleziensis (Hyatt, 1903) (Figure 16d and e); CY-20 and CY-22, discynid brachiopods (Figures $16 \mathrm{f}$ and 17a), Gerhardtia galeatoides (Karsten, 1858) (Figure 17b), and Crassatella? sp. (Figures 17c and 18h); CY-23, Heinzia sp. (Figure 17d) and Moutoniceras? sp. (Figure 17e); CY-24 and CY-25, Heinzia colleti (Bürgl, 1956) (Figures $17 \mathrm{f}$ and g) and Pseudohaploceras sp. (Figure 18i); and for the upper segment of the upper interval, in CY-30, Heinzia? sp. (Figure 17 h).
Based on the collected ammonoids in the upper interval, this stratigraphic succession involves deposits of the Upper Barremian, as indicated by the presence of the index species of the biozone of Gerhardtia veleziensis (cf. Patarroyo, 1999, $2000 \mathrm{a}$ and b, 2004, 2020). It is not possible to indicate a clear stratigraphic range for the highest deposits of the Yuruma Formation in Yuruma hill because the recovery of ammonoids in these strata unfortunately was not successful. Furthermore, it was not possible to describe there the succession until the boundary with the overlying "Cogollo" Formation. However, in the sector of Punta Espada, a few meters from the upper boundary of the Yuruma Formation and toward the base of the "Cogollo" Formation, Dufrenoyia cf. hansbuerglii Etayo-Serna of the Lower Aptian (Patarroyo and Götz, 2020) was found; thus, the possibility remains that part of the deposits in the upper segment of the upper interval in the Yuruma Formation may be represented the lowest part of the Lower Aptian.

Similarly, at Punta Espada, the sample PEY-1 contains Nicklesia sp. (Figure 17i) and Epistomina caracola, which were identified in the thin section of the same sample. This material is from the lower Barremian and is related to the lower stratigraphic level of the Yuruma Formation (Figure 11) in this sector of the Alta Guajira.

The citation of Pedioceras, P. caquesense or P. caquensense (sic) to the upper Barremian in the upper part of the Yuruma Formation (Rollins, 1960, p. 29, Figure 6, Figure 10; 1965, p. 53, Figure 6, Figure 10) is highly controversial because in the central Cretaceous marine deposits of Colombia, Pedioceras is restricted to the lower part of the lower Barremian (cf. Etayo-Serna, 1964; Patarroyo, 1995, 2000 a and b, 2004, 2020).

\subsection{Environmental considerations}

Considering the lithological, sedimentological and fossil variations, preliminary environmental interpretations of the sedimentary succession of the Yuruma hill can be proposed.

The environmental conditions of the upper part of the Moina Formation indicate currents with high energy levels over the bottom of the deposit, as demonstrated by the mechanical accumulation of mollusks (Figure 18a) and the fragmentation of shells and carapaces.

The sharp contact between the top bed of the Moina Formation and the lower bed of the Yuruma Formation (Figure 4) indicates a change in the sedimentary conditions of the medium since there is an increase in the content of calcareous mud without decreases benthic macrofauna. Thus, a transgressive 


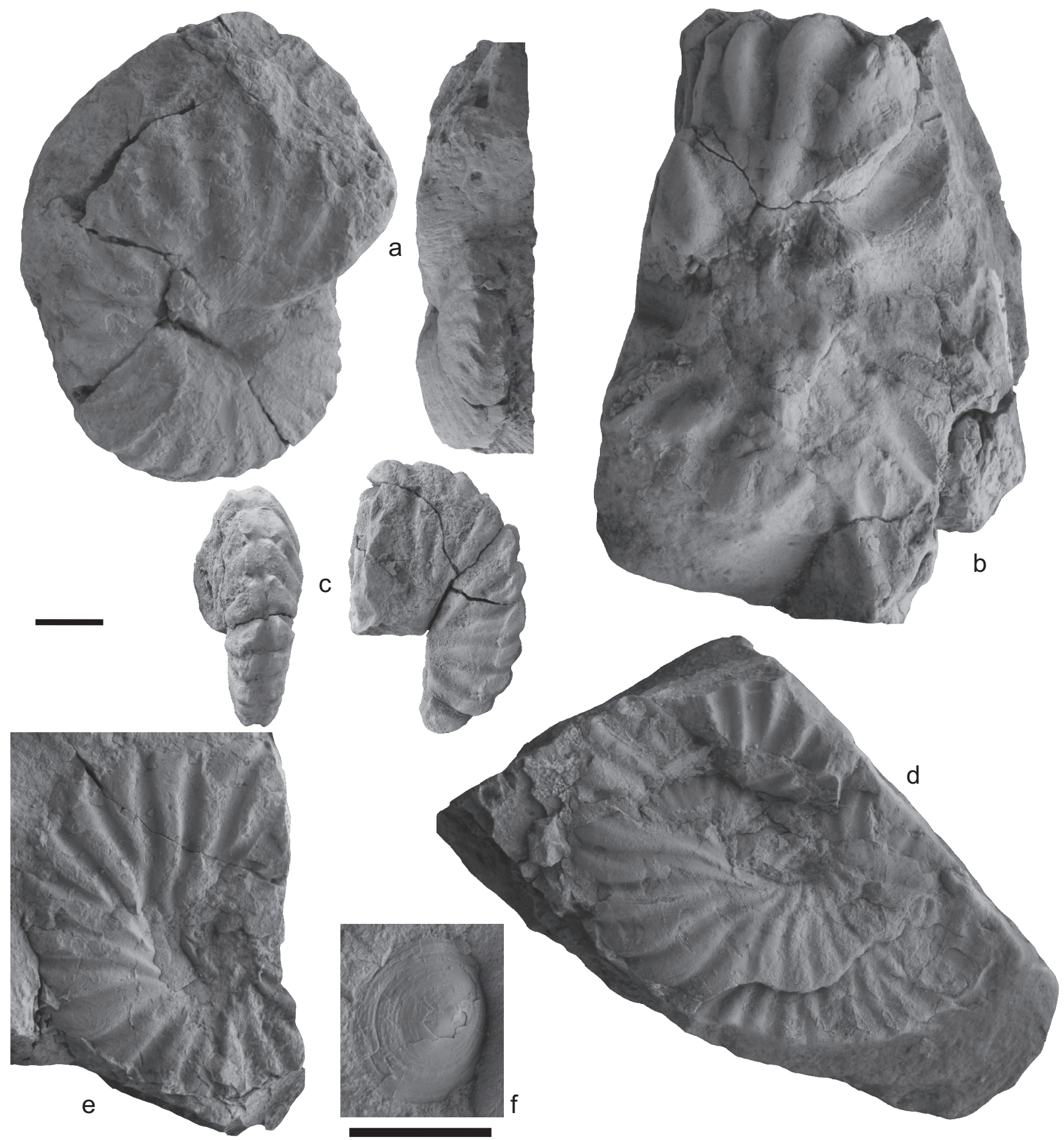

Figure 16. a) Pulchellia cf. fasciata (CY-17); b) Pulchellia sp. (CY-17); c) Pulchellia cf. galeata (CY-17); d and e) Gerhardtia veleziensis (CY-19 and CY-20); and f) discynid brachiopod (CY-20) [Graphic scales (a, e) $10 \mathrm{~mm}$ and (f) $5 \mathrm{~mm}$ ] 

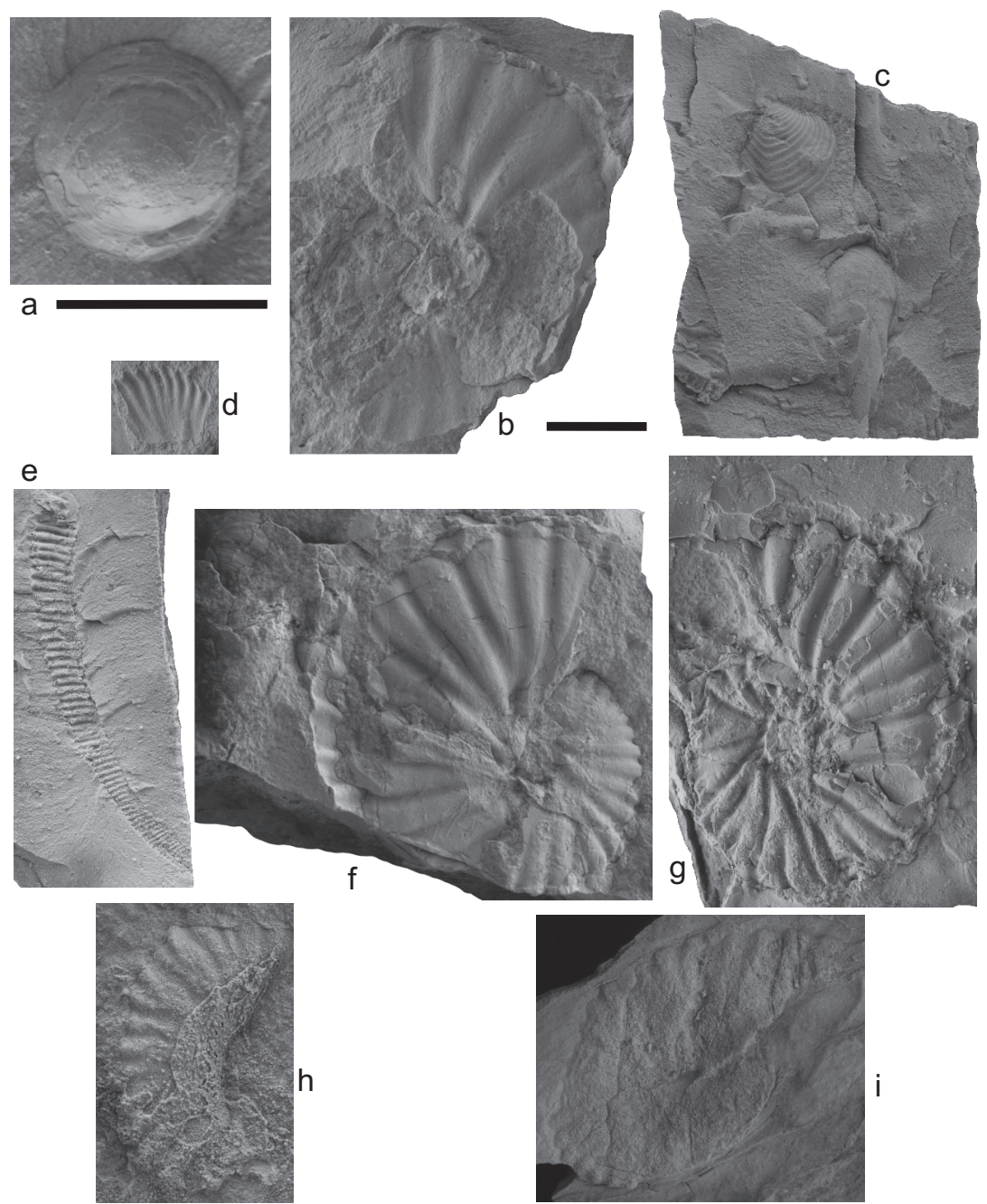

Figure 17. a) Brachiopod discynid (CY-22); b) Gerhardtia galeatoides (CY-22); c) Crassatella? sp. (CY-22); d) Heinzia sp. (CY-23); e) Moutoniceras? sp. (CY-23); f and g) Heinzia colleti (CY-24 and CY-25); h) Heinzia? sp. (CY-30); and i) Nicklesia sp. (PEY-1. Punta Espada) [Graphic scales (a) 5 mm and (b, i) $10 \mathrm{~mm}$ ]

surface is identified as a consequence of deepening of the bottom of the deposit and a decrease in energy levels. The alternation between very fossiliferous marlstones and biomicrites with irregular layers allows to interpret variations in the depth of the deposit bottom and consequently in the energy flow over it. These variations in the lower interval deposits were more constant in the lower segment than in the upper segment because the biomicrites are subordinate to the marlstones.

In the upper interval, calmer environmental conditions are identified as a result of a greater deepening of the bottom of the deposit. The tabular beds geometries and the continuous or discontinuous plane-parallel internal lamination, plus the scarce presence of benthic fauna, corroborate this postulate.

\subsection{Geology of Cerro Yuruma}

Considering the stratigraphic findings at the Yuruma hill and in its surroundings, it was possible to recognize and differentiate the deposits of the upper part of the Moina Formation in the Uarraramarirai or Uarramaralijai Stream (Figures 1c and 4); consequently, the sharp boundary of the base of the Yuruma Formation and from there, stratigraphically ascending, the following succession of the Yuruma Formation until the upper part of the Yuruma hill (overview, Figures 2 and 19).

Based on the data obtained in this contribution, related with the 10Bis-I-A topographic map of the IGAC (scale $1: 25,000)$, the lateral boundaries continuity between the formations was projected based on public satellite images, pano- 

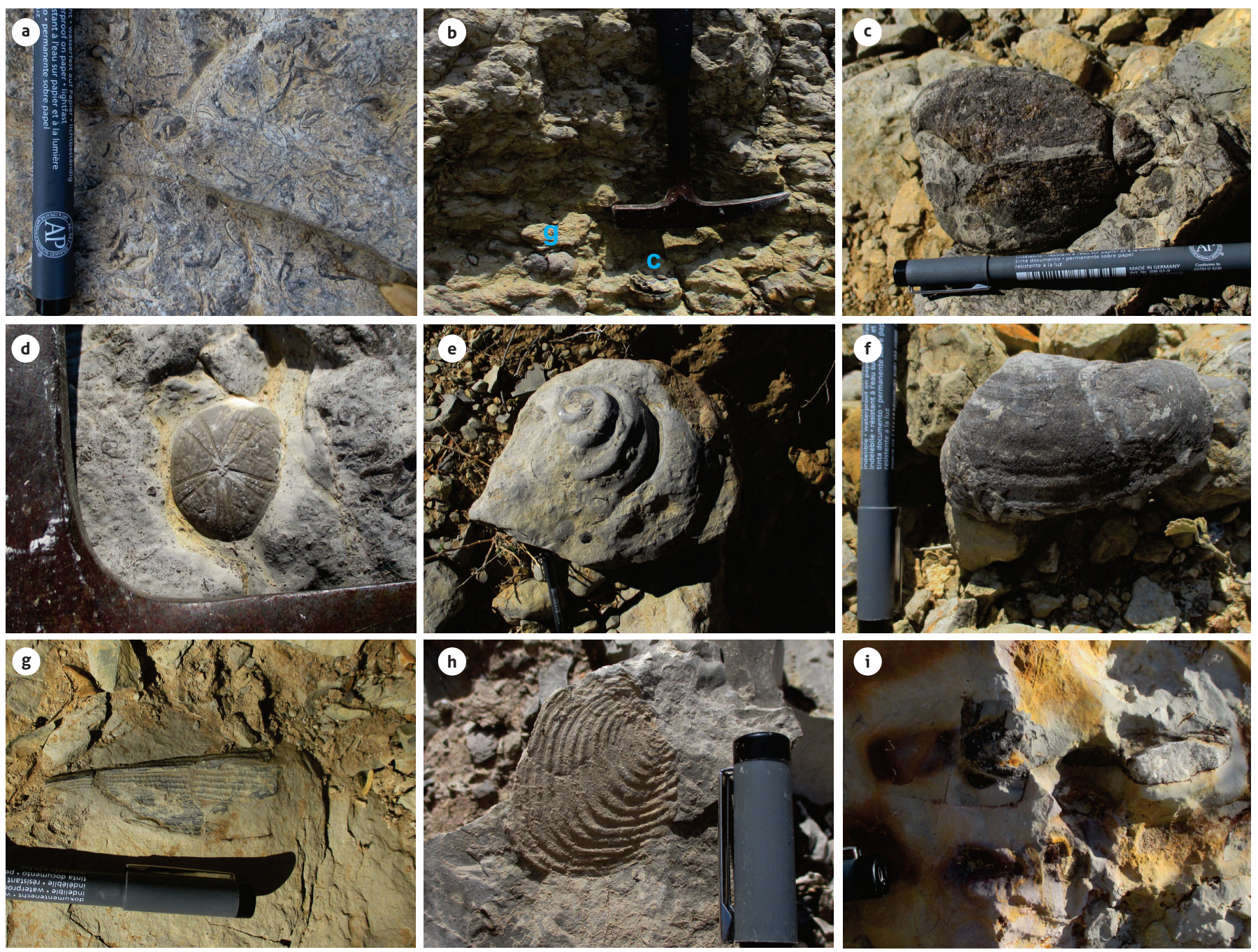

Figure 18. Other macrofossils of the Yuruma hill section that remain in the terrain

a) mechanical accumulation of mollusks in the upper part of the Moina Formation with Ceratostreon sp.; b) small gastropod (g) and Ceratostreon sp. (c) with articulated shells and parallel orientation to the bedding plane at the base of the Yuruma Formation; c) Cucullaea sp; d) irregular echinoid; e) internal mold of a large gastropod: f) Pholadomya sp.; g) Pinna sp.; h) Crassatella? sp.; and i) biomicrite bed with the whorl section of Pseudohaploceras sp. and parallel orientation to the bedding plane.

ramic observations, field controls (compass and GPS data) and the morphology of the lithostratigraphic units. Although the upper boundary of the Yuruma Formation with the base of the "Cogollo" Formation was not recognized in the adjacent area of the Yuruma hill, the morphological change between these units was considered (Figures 2 and 19), which is coincident with the proposition and mapping of Rollins (1960, 1965). Therefore, a geological map of this sector was obtained (Figure 19), which shows the relationship of the rocks of the Yuruma Formation, following Rollins $(1960,1965)$, with the underlying Moina Formation and with the overlying "Cogollo" Formation.
This last contact is sharp, according to Patarroyo and Götz (2020, Figure 2), as is recognized in the Punta Espada area.

The geological map, Plate 10Bis Rancho Grande (Yuruma hill) and Plate 6 Castilletes (Punta Espada) of Zuluaga et al. (2008 a and b) show different geological interpretations because they do not consider the same lithostratigraphic boundary between the Yuruma Formation and the "Cogollo" Formation. As it was discussed this boundary is taken following Rollins (1960 and 1965) to the Yuruma hill (panoramic Figure 19) and to Punta Espada area (cf. Patarroyo and Götz, 2020). 

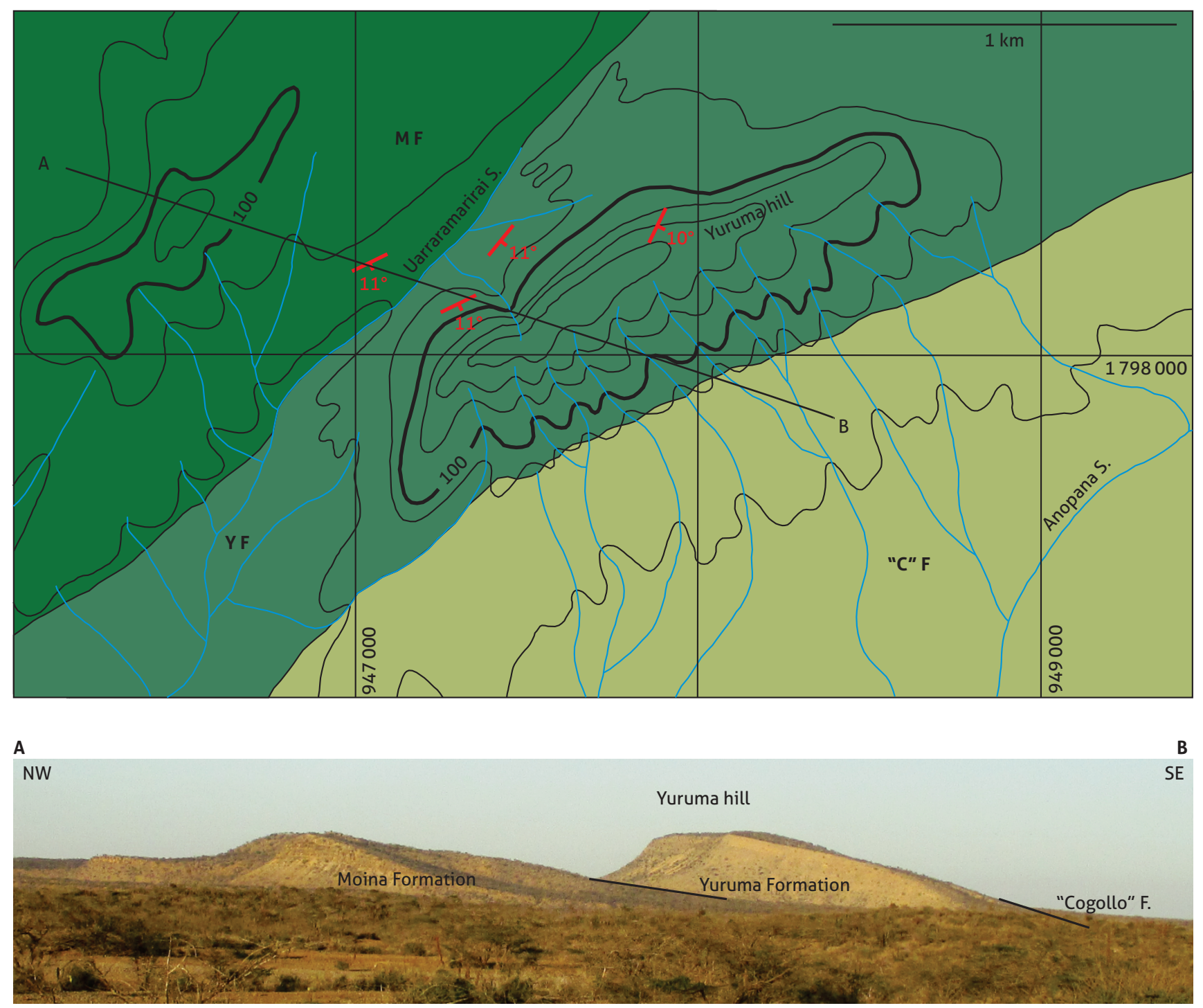

Figure 19. Geological map of the Yuruma hill area based on the 10Bis-I-A topographic map of the IGAC and obtained from field data, morphological expression, panoramic photographs and satellite images

The two stratigraphic intervals of the Yuruma Formation in the Yuruma hill present variable morphological characteristics; thus, initially in the relief, the succession is principally competent although incompetent beds appear as intercalations (Figures 4, 5, 7 and 8); in the intermediate part, a morphological depression is manifested by the predominance of incompetent beds (Figures 5, 7 and 9). Finally, for the upper part, there is a pronounced escarpment (Figures 5, 9 and 10). In the Yuruma hill and Punta Espada area, to the upper interval, karst phenomena are evident, so much so that in the upper sector of the Yuruma hill, travertine associated with speleothems is recognized.

The sharp contact between the highest bioclastic bed of the Moina Formation and the lower marlstone beds of the Yuruma Formation is associated with a morphological change representing a transgressive surface that was developed very close to the Hauterivian-Barremian boundary. At the top of the Yuruma Formation, the boundary with the marlstones of the "Cogollo" Formation is sharp, based on geological controls recognized in Punta Espada (Patarroyo and Götz, 2000) following the postulates of Rollins (1960 and 1965, Figure 6). 


\section{DISCUSSION}

The Yuruma Formation of the Barremian - lower Aptian? is a lithostratigraphic unit with marine deposits that are geologically associated with the Alta Guajira block. Its lower boundary is sharp with the Moina Formation at the type locality, as was recognized by Renz (1960) and Rollins (1960, 1965), and its upper boundary is sharp with the Cogollo Formation, following Rollins (1960, 1965). Based on the lithostratigraphic limits used here and the geomorphology of the Yuruma Formation, it is clearly better to follow the proposals of Rollins $(1960,1965)$ than those of Renz $(1960)$ to obtain a geological mapping.

The Yuruma Formation and the Moina Formation do not crop out to the south in the Perija Mountain range, where the type locality of the "Cogollo" Group or Formation is found (cf. Patarroyo and Götz, 2020). Care must be taken to extend regionally the lateral continuity of the lithostratigraphic units of the Perija Mountain range because the tectonic and paleotectonic of the Oca and Cuisa faults indicate that the northern blocks of the Alta Guajira were originally located to the west of their current position. This type of misstatement generates unnecessary stratigraphic confusion.

The paleotectonic, paleoecological and sedimentological deposits conditions of the Yuruma Formation are not directly related to the equivalent deposits of the central Cretaceous basin in Colombia, although they show similar biostratigraphic elements in the nektonic fauna, which enables the establishment of their stratigraphic range (cf. Patarroyo, 2020).

\section{Conclusions}

In the studied section of the Yuruma hill, the succession of the Yuruma Formation can be differentiated into two stratigraphic intervals, lower and upper intervals, which in turn can be subdivided into two segments each.

The lower interval is characterized by intercalations of very fossiliferous marlstones and biomicrites with benthic and nektonic fossils of the lower Barremian. Nicklesia pulchella, N. karsteni, N. cf. karsteni, Karsteniceras sp., K. beyrichi, K. cf. beyrichi, Neithea sp., Nododelphinula sp., Pulchellia sp., P. galeata, $P$. cf. galeata, $P$. caicedi, $P$. cf. caicedi, $P$. fasciata, $P$. cf. fasciata, Moutoniceras? sp., Pterotrigonia sp., Ceratostreon sp., Pinna sp., small and large gastropods, echinoderms, brachiopods and corals were found.
The upper interval is characterized by marlstones and biomicrites with scarce benthic and nektonic fauna of the upper Barremian and possibly part of the lower Aptian. Gerhardtia veleziensis, G. galeatoides, Heinzia sp., H. colleti, H.? sp., Moutoniceras? sp., Pseudohaploceras sp., Crassatella? sp. and discynid brachiopods are found. In the Punta Espada area, a few meters from the top of the Yuruma Formation, Dufrenoyia cf. hansbuerglii Etayo-Serna from the lower Aptian was found toward the base of the "Cogollo" Formation (Patarroyo and Götz, 2020).

Considering the lithological and sedimentological variations in the succession of the Yuruma hill, variable environmental conditions can be interpreted. At the top of the Moina Formation, the sea bottom experienced high energy influxes with the accumulation of shell and carapace fragments. In the lower deposits of the Yuruma Formation, there is a change in the environmental conditions of the deposit due to the presence of marls, an indicator of deepening for the lower interval succession where very fossiliferous marlstones and biomicrites with dominant benthic macrofossils are present. Then, there is a greater deepening related with the upper interval succession, where poor fossiliferous marlstones and biomicrites appear with scarce benthic and nektonic macrofossils.

\section{ACKNOWLEDGMENTS}

My sincere thanks to the communities of Wuatchuali and Punta Espada, to Edwar Salazar, and to the students of the field trip (2009) from the Department of Geosciences, Universidad Nacional de Colombia, for all the support provided. In the same way, I extend my gratitude to Jorge Gómez Tapias, María Fernanda Almanza, Lisbeth Fog and Alejandra Cardona (Servicio Geológico Colombiano) for their support, accompaniment and the opportunity to carry out the research on Yuruma hill. I also thank the two anonymous reviewers who contributed to the enrichment of this work.

\section{References}

Álvarez, W. (1967). Geology of the Simarua and Carpintero áreas, Guajira península, Colombia [Ph.D. Thesis]. Princeton University, USA.

Bürgl, H. (1956). Catálogo de las amonitas de Colombia. Parte I. Pulchelliidae. Instituto Geológico Nacional. Boletín Geológico, 4(1), 1-119. 
Bürgl, H. (1960). Geología de la Península de la Guajira. Servicio Geológico Nacional. Boletín Geológico, 6(1-3), 129-168.

Campbell, C. V. (1967). Lamina, Laminaset, bed and bedset. Sedimentology, 8, 7-26.

Colmenares, F., Román García, L., Sánchez, J. M., \& Ramírez, J. C. (2019). Diagnostic Structural Features of NW South America: Structural Cross Sections Besed Upon Detailed Fields Transects. In F. Cediel, \& R. P. Shaw (eds.), Geology and Tectonics of Northwestern South America, Frontiers in Earth Sciences. Chapter 9. Springer.

d'Orbigny, A. (1840). Paléontologie francaise. Terrains Crétacés. Céphalopodes. Tomo I. Masson.

Etayo Serna, F. (1964). Posición de las faunas en los depósitos cretácicos colombianos y su valor en la subdivisión cronológica de los mismos. Boletín de Geología, 16-17, 1-141.

Etayo-Serna, F. (1985). Paleontología estratigráfica del Sistema Cretácico en la Sierra Nevada del Cocuy. In F. Etayo-Serna, \& F. Laverde Montaño (eds.), Proyecto Cretácico (pp. XXIV1-XXIV47). Publicaciones Geológicas Especiales 16. Ingeominas.

Gerhardt, K. (1897). Beitrag zur Kenntniss der Kreideformation in Columbien. In G. Steinmann (ed.), Beiträge zur Geologie und Paläontologie von Südamerika, 5. Neues Jahrbuch für Mineralogie, Geologie und Palaeontologie, XI. Beilage-Band, 118-208.

Gómez, I. (2001). Structural style and evolution of the Cuisa Fault System, Guajira, Colombia [Master thesis]. University of Houston.

Guzmán, G. (1985). Los grifeidos infracretácicos Aetostreon couloni y Ceratostreon boussingaulti, de la Formación Rosablanca, como indicadores de oscilaciones marinas. In F. Etayo-Serna, \& F. Laverde Montaño (eds.), Proyecto Cretácico (pp. XII1-XII16). Publicaciones Geológicas Especiales 16. Ingeominas.

Hyatt, A. (1903). Pseudoceratites of the Cretaceous. USGS Monograph, 44, 1-250.

Irving, E. M. (1971). La evolución estructural de los Andes más septentrionales de Colombia. Boletín Geológico, 19(2), 1-89.

Jaworski, E. (1938). Gasterópodos del Cretácico inferior de Colombia. Estudios geológicos y paleontológicos sobre la cordillera Oriental de Colombia, parte tercera, folleto de texto. República de Colombia, Ministerio de Industrias y Trabajo, Departamento de Minas y Petróleos.
Julivert, M., Barrero, D., Botero Arango, G., Duque Caro, H., Hoffstetter, R., Navas, J., de Porta, J., Robbins, R. K., Taborda Arango, B., Téllez, N., \& Zamarreño de Julivert, I. (1968). Colombie. Précambrien, Paléozoïque, Mésozoïque, et intrusions d'âge mésozoïque - tertiaire. Lexique Stratigraphique International, $(\mathrm{V}, 4 \mathrm{a})$, première partie. Centre National de la Recherche Scientifique.

Karsten, H. (1858). Über die geognostischen Verhältnisse des westlischen Columbien, der heutigen Republiken Neu-Granada und Equador. Amtlicher Bericht über die 32 Versammlung der Deutschen Naturforscher und Ärzte zu Wien, 1856, 80-116.

MacDonald, W. D. (1964). Geology of the Serranía de Macuira Area. Guajira Peninsula, Colombia [Ph.D. Thesis]. Princeton University, USA.

MacDonald, W. D. (1965). Geology of the Serrania de Macuira area, Guajira Peninsula, Northeast Colombia. In J. B. Saunders (ed.), Transactions, Fourth Caribbean Geological Conference, 1965 (pp. 267-274). Caribbean Printers.

Patarroyo, P. (1999). Die Entwicklung der Ammoniten der Familie Pulchelliidae aus dem Barrême von Zentral-Kolumbien [Dr. Thesis]. Universität Giessen, Alemania.

Patarroyo, P. (2000a). Amonitas del Barremiano en Villa de Leyva-Boyacá (Colombia-Sur America): Datos bioestratigráficos preliminares. Zentralblatt der Geologie und Paläontologie, I, 789-798.

Patarroyo, P. (2000b). Distribución de amonitas del Barremiano de la Formación Paja en el sector de Villa de Leyva (Boyacá, Colombia): Bioestratigrafía. Geología Colombiana, 25, 149-162.

Patarroyo, P. (2004). Die Entwicklung der Ammoniten der Familie Pulchelliidae aus dem Barrême von Zentral-Kolumbien. Révue de Paléobiologie, 23(1), 1-65.

Patarroyo, P. (2011). Observaciones sobre la geología de las sedimentitas del Cretácico (Barremiano-Coniaciano) del sector de Punta Espada, Alta Guajira (Uribia-Guajira-Colombia). XIV Congreso Latinoamericano de Geología, XIII Congreso Colombiano de Geología [Memories], Medellín.

Patarroyo, P. (2020). Barremian deposits of Colombia: A special emphasis on marine successions. In J. Gómez, \& A. O. Pinilla-Pachón (eds.), The Geology of Colombia, Volume 2 Mesozoic (pp. 445-474). Publicaciones Geológicas Especiales 36. Servicio Geológico Colombiano. https://doi. org/10.32685/pub.esp.36.2019.12 
Patarroyo, P., \& Götz, S. (2013). Dufrenoyia y Amphitriscoelus en depósitos del Aptiano de la Formación Cogollo (Guajira - Colombia). XIV Congreso Colombiano de Geología, Bogotá.

Patarroyo, P., \& Götz, S. (2014). Aptian ammonite and rudist association, Cogollo Formation (Guajira, Colombia). Paleobiogeographic significance to North Colombia. 23rd Latin American Colloquium on Earth Sciences (abstracts). In C. Ifrim, P. Bengtson, F. J. Cueto Berciano, \& W. Stinnesbeck (eds.), 23rd International Colloquium on Latin American Earth Sciences, Abstracts and Programme. GAEA heidelbergensis 19 (p. 123). https://www.geow.uni-heidelberg.de/md/ chemgeo/geow/tagung/lak2014/lak2014_gaea19_small.pdf

Patarroyo, P., \& Götz, S. (2020). Depósitos del Aptiano inferior con amonitas y rudistas, Punta Espada, Alta Guajira (Uribia - Colombia). Litoestratigrafía y apreciaciones regionales. Boletín de Geología, 42(3), 227-241. https://doi.org/10.18273/ revbol.v42n3-2020010

Renz, O. (1956). Cretaceous in Western Venezuela and the Guajira (Colombia). 20 Congreso Geológico Internacional, México (pp. 1-13).

Renz, O. (1960). Geología de la parte sureste de la Península de la Guajira (República de Colombia). Mem. 1161, Congreso Geológico Venezolano, 1. Publicación Especial 3, 317-347. Ministerio de Minas e Hidrocarburos.

Rollins, J. F. (1960). Stratigraphy and Structure of the Goajira Peninsula, Northwestern Venezuela and Northeastern Colombia [Ph.D. Thesis]. University of Nebraska, USA.

Rollins, J. F. (1965). Stratigraphy and Structure of the Goajira Peninsula, Northwestern Venezuela and Northeastern Colombia. Papers from the University of Nebraska series. 76. https://digitalcommons.unl.edu/cgi/viewcontent.cgi?article $=1076 \&$ context $=$ univstudiespapers
Salazar, E. (2010). Análisis estratigráfico y determinación de ambientes de depósito para la Formación Palanz. Inicio de la sedimentación cretácica en la Alta Guajira, Colombia [Master Thesis]. Universidad Nacional de Colombia, Bogotá.

Uhlig, V. (1882). Die Wernsdorfer Schichten und ihre Äquivalente. Sitzungsberichte der kaiserlichen Akademie der Wissenschaften. Mathematisch-Naturwissenschaftliche, Classe 86, pp. 86-117.

Von Buch, L. (1838). Über den zoologischen Character der Secundär-Formationen in Süd-Amerika. Bericht über die zur Bekanntmachung geeigneten Verhandlungen der Königlichen Preussischen Akademie der Wissenschaften zu Berlin, 54-67.

Zuluaga, C., Ochoa A., Muñoz, C., Dorado, C., Guerrero, N., Martínez, A., Medina, P., Ocampo, E., Pinilla, A., Ríos P., Rodríguez, P., Salazar, E., \& Zapata, V. (2008a). Geología de la Plancha 6 Castilletes (Escala 1:100000). Universidad Nacional de Colombia - Ingeominas. http://recordcenter.sgc.gov. co/B12/23008010024231/mapa/pdf/2105242311300010.pdf

Zuluaga, C., Ochoa A., Muñoz C., Dorado, C., Guerrero, N., Martínez, A., Medina, P., Ocampo, E., Pinilla, A., Ríos P., Rodríguez, P., Salazar, E., \& Zapata, V. (2008b). Geología de la Plancha 10Bis Rancho Grande (1:100000). Universidad Nacional de Colombia - Ingeominas. http://recordcenter.sgc.gov.co/ B12/23008010024231/mapa/pdf/2105242311300014.pdf

Zuluaga, C., Ochoa A., Muñoz, C., Guerrero, N., Martínez, A., Medina, P., Pinilla, A., Ríos P., Rodríguez, P., Salazar, E., \& Zapata, V. (2009). Memoria de las planchas 2, 3, 5, y 6 (con parte de las planchas 4, 10 y 10bis) [Proyecto de investigación: Cartografía e historia geológica de la Alta Guajira, implicaciones en la búsqueda de recursos minerales]. Universidad Nacional de Colombia - Ingeominas. http:// recordcenter.sgc.gov.co/B12/23008010024231/documento/pdf/2105242311101000.pdf 